\title{
A CONCRETIZAÇÃO DOS DIREITOS FUNDAMENTAIS SOCIAIS ATRAVÉS DE POLÍTICAS E ORÇAMENTOS PÚBLICOS
}

\author{
Alex de Araújo Pimenta ${ }^{1}$ \\ Ana Paula Pinheiro Motta ${ }^{2}$ \\ Jairo Salvador de Souza ${ }^{3}$
}

\section{Resumo:}

Este trabalho tem por objetivo investigar o papel dos instrumentos de planejamento na efetivação dos direitos fundamentais sociais, em especial das políticas públicas e dos orçamentos. A pesquisa utilizou o método hipotético-dedutivo, a partir do cotejamento da produção doutrinária acerca do tema, com experiências práticas representadas por modelos que enunciam a superação do vão abissal entre a abstrata previsão normativa e a efetivação dos direitos fundamentais sociais no mundo real. Partindo-se da delimitação do conceito de políticas públicas, procurou-se explicitar a relação entre políticas públicas e Estado Democrático de Direito, delineando-se os contornos de sua anatomia e funcionalidade. Buscou-se ainda compreender a relação existente entre as políticas públicas e os direitos fundamentais, em especial o papel que aquelas exercem na concretização de tal gênero de direitos. Para tanto, desenvolveu-se a ideia de vedação à insuficiência e à inercia na produção e implementação de políticas públicas tendentes à concretização dos direitos fundamentais. Da mesma forma, investigou-se o papel do orçamento no controle da efetividade da realização dos direitos fundamentais sociais e sua relação com o princípio da gestão democrática.

Palavras-chave: Orçamento; Políticas públicas; Direitos fundamentais.

\section{INTRODUÇÃO}

A concretização de direitos fundamentais sociais, em especial daqueles denominados positivos, de índole prestacional, reclama a adoção de atos materiais para sua efetivação.

As promessas constitucionais que proclamam o direito à educação, à saúde, à moradia, ao lazer, entre tantas outras salvaguardas da cidadania, devem ser analisadas sob o prisma das obrigações delas decorrentes, e não simplesmente dos direitos abstratamente outorgados.

\footnotetext{
${ }^{1}$ Mestrando em Concretização dos Direitos Sociais, Difusos e Coletivos pelo UNISAL, Lorena/SP. Procurador Jurídico Municipal na autarquia RESENPREVI - Instituto de Previdência dos Servidores Públicos do Município de Resende-RJ. Professor universitário na AEDB e professor de direito na FAETEC-RJ. E-mail: procuradoralex@hotmail.com

${ }^{2}$ Mestranda em Direito e Executiva Pública na Diretoria de Ensino - Região Guaratinguetá - da Secretaria da Educação do Estado de São Paulo. E-mail: anapaula-elias@ig.com.br

${ }^{3}$ Defensor Público do Estado de São Paulo. Mestrando em Direito do Centro Universitário Salesiano - UNISAL, campus Lorena/SP. E-mail: jairosalvador@globo.com
} 
A investigação dos instrumentos jurídicos, políticos e econômicos que permitiriam, em tese, a transposição do abismo entre a previsão abstrata e a concreta efetivação de tais direitos revela-se de grande importância para a compreensão da exigibilidade dos direitos fundamentais sociais.

Dentre os instrumentos de planejamento tendentes à concretização dos direitos sociais, as políticas e os orçamentos públicos assumem destacado papel, na medida em que trazem ao mundo jurídico a forma e as estratégias imaginadas pelo Poder Público para o atingimento dos objetivos fundamentais da República.

É sobre tais instrumentos, suas anatomias e a relação existente entre eles e a concretização dos Direitos fundamentais sociais que se volta o presente estudo, tendo por início a questão das políticas públicas.

\section{AS POLÍTICAS PÚBLICAS}

As políticas públicas constituem um instrumento privilegiado para a materialização dos direitos sociais, sendo o termo "políticas públicas" indissociável da realização dos objetivos fundamentais do Estado.

Osvaldo Canela Junior sustenta que as políticas públicas são o veículo material para a realização dos direitos fundamentais sociais ${ }^{4}$, afirmando que:

[...] são todas aquelas atividades desenvolvidas pelas formas de expressão do poder estatal tendentes à realização dos objetivos insculpidos no art. $5^{\circ}$ da Constituição Federal. Entre estes objetivos, destaca-se a efetivação dos direitos fundamentais, com especial enfoque para a igualdade substancial $[. . .]^{5}$

Em sentido idêntico, Ada Pelegrini Grinover esclarece que políticas públicas são constituídas de "programas e açôes tendentes ao atingimento dos objetivos do Estado brasileiro".

Ainda sobre o tema, o ex-Ministro do Supremo Tribunal Federal, Eros Grau, afirma que:

[...] a expressão política pública designa atuação do Estado, desde a pressuposição de uma bem demarcada separação entre Estado e Sociedade [...]. A expressão políticas públicas designa todas as atuações do Estado, cobrindo todas as formas de intervenção do poder público na vida social?

\footnotetext{
4 "Por política estatal - ou políticas públicas - entende-se o conjunto de atividades do Estado tendentes a seus fins, de acordo com metas a serem atingidas. Trata-se de um conjunto de normas (Poder Legislativo), atos (Poder Executivo) e decisões (Poder Judiciário) que visam à realização dos fins primordiais do Estado. (...). Como toda atividade política (políticas públicas) exercida pelo Legislativo e pelo Executivo deve compatibilizar-se com a Constituição, cabe ao Poder Judiciário analisar, em qualquer situação e desde que provocado, o que se convencionou chamar de 'atos de governo' ou 'questões políticas', sob o prisma do atendimento aos fins do Estado (art. $3^{\circ}$ da CF)". CANELA JUNIOR, Osvaldo. Controle judicial de políticas públicas. São Paulo: Saraiva, 2011, p.58.

5 Ibid., p. 57.

${ }^{6}$ GRINOVER, Ada Pelegrini. O Controle de Políticas Públicas pelo Poder Judiciário. Revista do Curso de Direito da Faculdade de Humanidades e Direito, v. 7, n. 7, 2010, p. 25.

${ }^{7}$ GRAU, Eros Roberto. O direito posto e o direito pressuposto. São Paulo: Malheiros, 2003, p. 26. 
Ronald Dworkin, em célebre debate travado com H.L.A. Hart ${ }^{8}$, estabelece uma nítida distinção entre regras (rules), princípios (principles) e políticas públicas (policies). Tal distinção ocorre no marco do desenvolvimento de sua teoria de justiça como integridade, promovendo o resgate do conteúdo moral do Direito.

Para Dworkin, políticas públicas seriam:

[...] aquele tipo de padrão que estabelece um objetivo a ser alcançado, em geral uma melhoria em algum aspecto econômico, político ou social da comunidade (ainda que certos objetivos sejam negativos pelo fato de estipularem que algum estado atual deve ser protegido contra mudanças adversas). ${ }^{9}$

As políticas públicas se diferenciariam dos princípios, já que estes constituem "um padrão que deve ser observado não porque vá promover ou assegurar uma situação econômica, política ou social considerada desejável, mas porque é uma exigência de justiça ou equidade ou alguma outra dimensão da moralidade”. ${ }^{10}$

O sentido atribuído por Dworkin às regras se assemelha ao desenvolvido posteriormente por Alexy, para quem as regras seriam espécies de normas de caráter binário, que são sempre satisfeitas ou não satisfeitas, veiculando sempre determinações no âmbito do que é possível fática e juridicamente.

Para Dworkin, entretanto, regras e princípios não seriam espécies do gênero norma, como sustentado por Alexy, nem tampouco guardariam qualquer relação hierárquica, distinguindo-se apenas pela "natureza da orientação que oferecem". ${ }^{11}$ A relevância da distinção oferecida por Dworkin reside no resgate do conteúdo ético do direito. No entanto, a delimitação dos contornos das políticas públicas, sua distinção em relação a regras e princípios, como traçado por ele, tem outro objetivo: expor a incoerência da concepção positivista clássica quando permite ao magistrado, nos casos difíceis, "criar" o direito, justificando tal criação em argumentos de política pública.

Como se pode ver, neste passo inicial, a anatomia do incipiente conceito jurídico de políticas públicas já desvela a existência de um dever fundamental, cujo conteúdo diz com a persecução do atingimento dos objetivos do Estado brasileiro, e que tem por sujeito passivo principal o próprio Estado.

Antes de prosseguir, entretanto, faz-se necessário estabelecer a relação entre políticas pública e Estado Democrático de Direito.

\section{Políticas Públicas e Estado Democrático de Direito}

A previsão constitucional da República Federativa do Brasil como um Estado Democrático de Direito concretiza uma garantia ao cidadão de participação, direta ou indireta, nas decisões políticas e, ainda, de atuação,

\footnotetext{
${ }^{8} \mathrm{~V}$. nota no 3 .

${ }^{9}$ DWORKIN, Ronald. Levando os direitos a sério. Trad. Nelson Boeira. São Paulo: Martins Fontes, 2011, p. 36.

${ }^{10}$ Ibid., p.36.

${ }^{11}$ Ibid., p.39.
} 
quer seja de administrados, quer seja de administradores, limitada às regras de direito vigentes.

Esta contenção de atuação pelo Direito direciona efetivamente o exercício do poder pelo Estado uma vez que este, além de ter o dever de agir de acordo com as diretrizes traçadas pelas normas, tem, ainda, a obrigação de atuar ativamente na concretização das mesmas.

Tal entendimento é expresso por Inocêncio Mártires Coelho na seguinte passagem:

Em que pesem pequenas variações semânticas em torno desse núcleo essencial, entende-se como Estado Democrático de Direito a organização política em que o poder emana do povo, que o exerce diretamente ou por meio de representantes, escolhidos em eleições livres e periódicas, mediante sufrágio universal e voto direto e secreto, para o exercício de mandatos periódicos, como proclama, entre outras, a Constituição brasileira. Mais ainda, já agora no plano das relações concretas entre o Poder e o indivíduo, considera-se democrático aquele Estado de Direito que se empenha em assegurar aos seus cidadãos o exercício efetivo não somente dos direitos civis e políticos, mas também e sobretudo dos direitos econômicos, sociais e culturais, sem os quais de nada valeria a solene proclamação daqueles direitos. $^{12}$

Para consolidação de ações tendentes à realização das normas de Direito vigentes, necessária se faz a decisão, elaboração, implementação e avaliação de políticas por parte dos Entes Estatais. Estas políticas são denominadas públicas.

$\mathrm{Na}$ verdade, há diferentes entendimentos quanto ao protagonismo no estabelecimento de políticas públicas. Sobre isso, Secchi se expressa em termos de que há posições doutrinárias que defendem a abordagem estatista - Estado como ator protagonista - e outras que defendem abordagens multicêntricas - atores estatais e não estatais. ${ }^{13}$

Assim, diferentes segmentos, como exemplo os movimentos sociais organizados, podem estar envolvidos no desenvolvimento de políticas públicas. Aliás, é através de participações como esta que torna-se possível a democratização da administração pública. Interessante a colocação de Dias e Matos:

No conjunto de atividades que tem como referência a polis, ou seja, o Estado, este pode ser o sujeito ou o objeto de ação. O Estado é sujeito pelo fato de pertencer à esfera da política, com atos como o de comandar ou proibir algo, ou o exercício do domínio exclusivo sobre um determinado território, o de legislar com normas válidas que se impõem a todos, o de extrair e distribuir recursos de um setor para outro da sociedade e assim por diante. O Estado é objeto da ação quando partem da sociedade civil iniciativas que visam influenciar de alguma forma a ação do Estado. ${ }^{14}$

É certo que, característica comum a todos os envolvidos neste protagonismo é a convergência de atuações num só sentido: elaborar diretrizes e concretizar ações que repercutam positivamente na vida dos cidadãos.

\footnotetext{
${ }^{12}$ MENDES, Gilmar Ferreira; COELHO, Inocêncio Mártires; BRANCO, Paulo Gustavo Gonet. Curso de Direito Constitucional. São Paulo: Saraiva, 2009, p. 171.

${ }^{13}$ SECCHI, Leonardo. Políticas públicas: conceitos, esquemas de análise, casos práticos. São Paulo: Cengage Learning, 2010, p. 02.

${ }^{14}$ DIAS, Reinaldo; MATOS, Fernanda. Políticas Públicas: princípios, propósitos e processos. São Paulo: Atlas, 2012, p. $02-03$. vol.07, nº. 02, Rio de Janeiro, 2014. pp. 617-657 
Referida atuação mostra-se complexa já que objetiva interferir na convivência de indivíduos com características e objetivos distintos.

Assim, as políticas a serem definidas deverão considerar uma intensa diferenciação social que caracterizase não só por peculiaridades físicas e objetivos diversos, mas, principalmente, por valores diferenciados.

\section{Significação do termo}

Quanto ao significado do termo política, cumpre primeiramente destacar o esclarecimento de Bobbio:

Derivado do adjetivo originado de pólis (politikós), que significa tudo o que se refere à cidade e, conseqüentemente, o que é urbano, civil, público, e até mesmo sociável e social, o termo Política se expandiu graças à influência da grande obra de Aristóteles, intitulada Politica, que deve ser considerada como o primeiro tratado sobre a natureza, funções e divisão do Estado, e sobre as várias formas de Governo, com a significação mais comum de arte ou ciência do Governo, isto é, de reflexão, não importa se com intenções meramente descritivas ou também normativas, dois aspectos dificilmente discrimináveis, sobre as coisas da cidade. ${ }^{15}$

Mais adiante o mesmo autor define uma significação clássica e uma moderna do termo:

[...] O termo Política foi usado durante séculos para designar principalmente obras dedicadas ao estudo daquela esfera de atividades humanas que se refere de algum modo às coisas do Estado [...]. Na época moderna, o termo perdeu seu significado original, substituído pouco a pouco por outras expressões como "ciência do Estado", "doutrina do Estado", "ciência política", "filosofia política", etc., passando a ser comumente usado para indicar a atividade ou conjunto de atividades que, de alguma maneira, têm como termo de referência a pólis, ou seja, o Estado. ${ }^{16}$

Dos vários conceitos relacionados ao termo destacamos três, trazidos pelo Dicionário Aurélio da Língua Portuguesa, quais sejam: "Arte de bem governar os povos"; "Conjunto de objetivos que enformam determinado programa de ação governamental e condicionam a sua execução" e "Habilidade no trato das relações humanas, com vista à obtenção dos resultados desejados".

Esta ampla conceituação nos mostra que "política", como arte, ciência ou qualquer outra forma de expressão, está relacionada às ações que interferem no cotidiano de cada membro da sociedade, na forma de viver, agir e se relacionar destes.

Segundo Aristóteles “Não entra no plano da Política determinar o que pode convir a cada indivíduo, mas sim o que convém à pluralidade [...]”. ${ }^{17}$

Importante, então, a priorização das necessidades em geral, de tudo aquilo que possa assegurar aos diversos cidadãos a possibilidade de uma vivência feliz, com um tratamento pacífico e eficaz dos acontecimentos e problemas sociais. Para isso, a sociedade age através do desenvolvimento da política.

\footnotetext{
${ }^{15}$ BOBBIO, Norberto; MATTEUCCI, Nicola; GIANFRANCO, Pasquino. Dicionário de Política. Brasília: UnB, 1986, p. 954.

${ }^{16}$ BOBBIO, Norberto; MATTEUCCI, Nicola; GIANFRANCO, Pasquino. Dicionário de Política. Brasília: UnB, 1986, p. 954

${ }^{17}$ ARISTÓTELES. A política. Tradução Roberto Leal Ferreira. 3. ed. São Paulo: Martins Fontes, 2006, p. 59. 
Na língua inglesa duas faces específicas da política são dispostas: politics e policy.

De acordo com Rua, a primeira expressão refere-se às atividades políticas como "uso de procedimentos diversos que expressam relações de poder (ou seja, visam a influenciar o comportamento das pessoas) e se destinam a alcançar ou produzir uma solução pacífica de conflitos relacionados a decisões públicas.". ${ }^{18}$

Já em relação à conotação policy sustenta referida autora que "[...] é utilizado para referir-se à formulação de propostas, tomada de decisões e sua implementação por organizações públicas, tendo como foco temas que afetam a coletividade, mobilizando interesses e conflitos [... ${ }^{\prime \prime}{ }^{19}$

O termo "público", segundo Dias e Matos apreende o domínio da atividade humana que é tido como necessário para a intervenção do Estado ou para a ação comum. ${ }^{20}$

Assim, o sentido de politics está relacionado ao conceito de políticas publicas como processo de tomada de decisões a fim de definir diretrizes e transformá-las em ações, estas voltadas ao bem comum.

Em complementação, assevera Rua: "Avançando um pouco mais, é possível sustentarmos que as políticas públicas (policy) são uma das resultantes da atividade política (politics): compreendem o conjunto das decisões e ações relativas à alocação imperativa de valores envolvendo bens públicos". ${ }^{21}$

A formulação de políticas públicas envolve decisões, e respectivas aplicações, que nortearão a vida coletiva, quer seja na resolução de problemas prioritários, quer seja na consolidação de esferas de convivência cada vez mais estruturadas e otimizadas. O objetivo é assegurar a todos uma maneira de viver entendida e sentida como realmente feliz.

Neste contexto, importante a atuação do Ente Estatal na identificação das demandas sociais e posterior intervenção positiva, que pode ocorrer através da elaboração de estratégias potencialmente modificadoras das realidades expostas e aplicação concreta das mesmas.

Nesta orientação Aristóteles afirma:

Todo Estado es, evidentemente, una asociación, y toda asociación no se forma sino en vista de algún bien, puesto que los hombres, cualesquiera que ellos sean, nunca hacen nada sino en vista de lo que les parece ser bueno. Es claro, por tanto, que todas las asociaciones tienden a un bien de cierta especie, y que el más importante de todos los bienes debe ser el objeto de la más importante de las asociaciones, de aquella que encierra todas las demás, y a la cual se llama precisamente Estado y asociación política. 22

No desenvolvimento deste processo confere-se ao Estado liderança nas decisões já que, mesmo que haja o envolvimento de outros atores no atendimento às diversas demandas sociais, o domínio das ações é de competência do Estado.

\footnotetext{
${ }^{18}$ RUA, Maria das Graças. Políticas Públicas. CAPES: UAB, 2009, p. 18.

${ }^{19}$ Ibid., p. 19.

${ }^{20}$ DIAS; MATOS, op. cit.

${ }^{21}$ RUA, op. cit., 2009, p. 19.
}

${ }^{22}$ ARISTÓTELES. Política. Disponível em: <http://www.dominiopublico.gov.br>. Acesso em: 07 jul. 2013. 
Isto se justifica pela própria formação do Estado que, como sociedade politicamente organizada, possuidora de poder, estabelece regras de convivência entre os cidadãos e se mantem como principal articulador destas.

Sobre isso, Dias e Matos se expressam na seguinte afirmação:

No final do século XX ocorre uma crise do Estado do Bem-Estar Social, que não consegue atender ao aumento da complexidade das demandas sociais, há um redimensionamento do setor público, que deixa de ser exclusivamente estatal, convertendo-se num espaço de articulação onde indivíduos e organizações não governamentais atuam e compartilham responsabilidades com os órgãos de governo em temas pontuais nos quais assumem a condição de especialistas.

Nesse contexto, a atuação governamental assume maior complexidade na medida em que os diversos fragmentos nos quais se articula [...] passam a ter que desenvolver políticas públicas sempre em interação com ONGs que atuam na área. Nesse sentido, a governabilidade ocorre num compartilhamento de ações conjuntas entre setores estatais, organizações não governamentais e setor privado [...] que passam a responsabilizar-se pela execução de políticas públicas em áreas determinadas [...] Nesse caso, o Estado continua a ter o papel central, no entanto, a gestão pública passa a ser compartilhada com outros agentes, embora sob a direção e controle do Estado. ${ }^{23}$

Assim, tomemos em linha de conta o Programa Bolsa Família, que integra o Plano Brasil sem Miséria. ${ }^{24}$

Este é um programa de transferência direta de renda que beneficia famílias em situação de pobreza e de extrema pobreza em todo o País.

Para efetivação deste programa necessário se fez, a princípio, identificar situações de pobreza e extrema pobreza no Brasil. A partir daí, foram traçadas diretrizes e a intervenção definida para alteração positiva desta realidade foi a criação da Lei 10.836/2004 - regulamentada pelo Decreto 5.209/2004 - garantidora de benefício financeiro às famílias que preencham determinados requisitos.

A gestão do Bolsa Família é descentralizada e os entes federados trabalham conjuntamente para aperfeiçoar, ampliar e fiscalizar a execução do Programa.

Entretanto, o envolvimento de outros atores na fiscalização deste programa resultou em denúncias de recebimento indevido do benefício, o que, certamente, colaborou para o aperfeiçoamento do programa.

Daí porque sustentamos que o desenvolvimento das políticas públicas deve ocorrer em interação com os atores não estatais a fim de que as ações sejam otimizadas e geradoras de mudanças positivas e eficazes no contexto social.

Por fim, destacamos o entendimento de Marta M. A. Rodrigues, que muito bem sintetiza o contexto de concretização das políticas públicas:

Jogar o jogo da política democrática, ética, e da justiça social é o desafio que os gestores de políticas públicas têm de enfrentar para planejar, administrar e extrair recursos e formatar

\footnotetext{
${ }^{23}$ DIAS; MATOS, op. cit., p. 27.

${ }^{24}$ BRASIL. Ministério do Desenvolvimento Social. Disponível em: <www.mds.gov.br>. Acesso em: 07 jul. 2013. 
políticas redistributivas que busquem promover sociedades mais iguais e mais livres, num contexto mundial de profundas mudanças econômicas, demográficas e ideológicas.

Em suma, da capacidade do Estado (pelos diversos governos) para executar políticas públicas sociais mais eficazes, abrangentes e universais depende o aprimoramento do bemestar e da cidadania, com a diminuição das desigualdades e a consolidação da democracia de cidadãos e cidadãs. ${ }^{25}$

\section{Ciclo de Políticas Públicas}

Para o desenvolvimento mais eficiente do processo de implementação de políticas públicas foi constituída uma divisão sequencial de etapas do processo. Tal divisão é denominada "ciclo de políticas públicas".

Em relação às fases deste ciclo, vários são os entendimentos.

Segundo Rua, o processo de elaboração de políticas públicas envolve as seguintes fases: Formação de agenda; Definição do Problema; Análise do Problema; Formação de Alternativas; Tomada de Decisão: adoção da política; Implementação; Monitoramento; Avaliação e Ajuste. Em complemento assevera a autora:

[...] as etapas são compreendidas não como um processo linear, mas como uma unidade contraditória, em que o ponto de partida não está claramente definido e atividades de etapas distintas podem ocorrer simultaneamente ou as próprias etapas podem apresentar-se parcialmente supostas. ${ }^{26}$

Já Secchi considera que, mesmo havendo diferentes formas de visualizar o ciclo de políticas públicas, sete são as principais fases:

1) Identificação do problema;

2) Formação da agenda;

3) Formulação de alternativas;

4) Tomada de decisão;

5) Implementação;

6) Avaliação;

7) Extinção. $^{27}$

Sobre o assunto, ressaltamos, ainda, o entendimento de Dias e Matos:

Os ciclos ou processos de políticas constituem um modelo de análise que decompõe a política pública em uma série de etapas que formam uma sequência lógica, constituindo uma ferramenta proposta pela primeira vez por Charles Jones em 1970. Desde então, são cinco as fases na vida ou desenvolvimento de uma política pública que mais são utilizadas: identificação de um problema, formulação de soluções, tomada de decisões, implementação e avaliação. (Grifo nosso).

Este modelo de análise tem como vantagem apresentar a política pública como uma sucessão de sequências correspondendo a uma abordagem clássica e racional da política

\footnotetext{
${ }^{25}$ RODRIGUES, Marta M. A. Políticas públicas. São Paulo: Publifolha, 2011, p. 78.

${ }^{26}$ RUA, op. cit., p. 37.

${ }^{27}$ SECCHI, Leonardo. Políticas públicas: conceitos, esquemas de análise, casos práticos. São Paulo: Cengage Learning, 2010, p. 02. vol.07, nº. 02, Rio de Janeiro, 2014.pp. 617-657 
envolvendo diferentes cenários e atores. O modelo é aplicável na análise de qualquer política, além de facilitar a delimitação do objeto de estudo. ${ }^{28}$

Assim, o procedimento de formulação das políticas públicas envolve várias atividades políticas que podem ser avaliadas e modificadas a fim de que o processo político seja sempre aperfeiçoado.

Certo é que o ciclo de políticas públicas passa a ser observável sob diferentes aspectos devido à participação de diversos atores e níveis de decisão. Desse modo, cada fase do ciclo de políticas públicas deve identificar seus objetivos e priorizar os resultados dentro dos limites que lhe são característicos. Isto possibilitará que cada etapa influencie positivamente sobre a outra.

Importante notar que o processo de formulação das políticas é extremamente dinâmico e o limite entre uma etapa e outra nem sempre é identificável.

A fim de analisarmos as fases sequenciais do ciclo de políticas públicas consideraremos a disposição sistemática trazida por Rua. ${ }^{29}$

\section{Diferentes momentos de uma politica pública}

a- $\quad$ Formação de Agenda

No processo de formação das políticas públicas, ao se identificar um problema verifica-se sua relevância social e, a partir daí, prioriza-se a atuação dos atores na resolução da demanda. Deve-se considerar, ainda, a real necessidade das possíveis intervenções.

Como exemplo de Agenda podemos ter um programa de governo ou um planejamento orçamentário, por exemplo.

Importante nesta fase é definir se a demanda realmente exige intervenção pública.

b- Definição do Problema

As demandas sociais dificilmente ocorrem isoladamente já que fatores diversos podem ocorrer simultaneamente às mesmas, como exemplo, uma questão educacional que geralmente está envolvida com a condição social e financeira da família do educando.

Por esta razão, definir um problema exige a verificação da real existência de situação tida como insatisfatória pela coletividade, sua abrangência, contexto em que se desenvolve e fatores interligados e delimitação do enfoque.

Dias e Matos se expressam no sentido de que:

Em termos metodológicos, para se abordar um problema público em toda sua complexidade e simplificar sua compreensão sem comprometer sua estrutura inicial, é necessário reconstruir as relações dentro de uma sequência de problemas que culminaram no problema

\footnotetext{
${ }^{28}$ DIAS; MATOS, op. cit., p. 63.

${ }^{29}$ RUA, op.cit.
} 
principal, fazendo as ligações de causa e efeito, melhorando, dessa forma, a análise global da problemática estudada $[. ..] .^{30}$

Um aspecto importante a ser considerado é que problemas podem ser redefinidos e adaptados pelos atores durante o ciclo de políticas públicas. Importante, assim, analisar constantemente referida demanda social. c- $\quad$ Análise do Problema

Esta fase caracteriza-se pelo exame crítico das partes componentes do problema. Isto possibilita uma percepção real do nível de complexidade da demanda facilitando a visualização das formas mais eficazes de resolução desta.

\section{c.1- Formação de Alternativas}

A partir do efetivo conhecimento do problema constante na Agenda importante, então, definir formas de solução deste. Para isto, deve-se ter em conta quais as consequências que este problema pode gerar e qual a abrangência, efetividade e custo de cada alternativa estipulada.

Quanto ao tema, Secchi se expressa no sentido de que a definição de alternativas envolve o estabelecimento de métodos, programas, estratégias ou ações que poderão atingir os resultados desejados inicialmente e que é possível se chegar a um mesmo objetivo através de várias formas e caminhos. ${ }^{31}$

E continua referido autor:

O policymaker tem à disposição quatro mecanismos para indução de comportamento:

1. Premiação: influenciar comportamento com estímulos positivos [...]

2. Coerção: influenciar comportamento com estímulos negativos [...]

3. Conscientização: influenciar comportamento por meio da construção e apelo ao senso de dever moral [...]

4. Soluções técnicas: não influenciar comportamento diretamente, mas sim aplicar soluções práticas que venham a influenciar comportamento de forma indireta $[. . .]^{32}$

A adoção de qualquer destes mecanismos traz custos financeiros e temporais que também devem ser considerados na formulação das possibilidades de atuação.

Lembrando que as alternativas geralmente expressam interesses diversos, entretanto, estes interesses devem ser conciliados a fim de se alcançar o bem comum.

d- Tomada de Decisão: adoção da política

É o momento de escolha das alternativas propostas anteriormente. Nesta fase, deve-se considerar que cada política pública que venha a ser estabelecida acarretará mudanças no contexto social e influenciará a vida dos cidadãos.

\footnotetext{
${ }^{30}$ DIAS; MATOS, op. cit., p. 70.

${ }^{31}$ SECCHI, op. cit.

${ }^{32}$ Ibid., p. 38.
} 
Secchi entende que há três formas de entender o procedimento de escolha sob a perspectiva dos tomadores de decisão: têm problemas em mãos e correm atrás de soluções; vão ajustando os problemas às soluções, e as soluções aos problemas ou; têm soluções em mãos e buscam problemas. ${ }^{33}$

Qualquer que seja a forma utilizada para decisão da política deve sempre manter-se comprometida com a os objetivos traçados no início do processo a fim de que sejam alcançados os resultados esperados.

e- Implementação

Neste momento, todas as definições de atuação definidas passam a ser aplicadas no contexto social através de ações concretas. Isto possibilita, aos atores envolvidos, a verificação da adequação de todas as ações e entendimentos propostos até então.

Nesse sentido, Rua sustenta que a implementação constitui-se de decisões sobre a operação das rotinas executivas das várias organizações envolvidas em uma política acarretando uma intervenção na realidade. ${ }^{34}$

Esta intervenção é complexa sob o ponto de vista da eficácia, já que as ações efetivadas deverão ser aceitas e realmente respeitadas pelos cidadãos sob pena de produzir o resultado desejado.

Por esta razão mostra-se de extrema importância neste momento o desenvolvimento da política pelo Ente Estatal em interação com outros atores, grupos e instituições. Esta participação intensifica a complexidade da fase de implementação ao envolver pessoas com valores, competências e interesses diversos, entretanto, aumenta a probabilidade de que as ações propostas sejam realmente eficazes.

Secchi, ao falar sobre o momento da Implementação, expõe o seguinte entendimento:

A importância de estudar a fase de implementação está na possibilidade de visualizar, por meio de instrumentos analíticos mais estruturados, os obstáculos e as falhas que costumam acometer essa fase do processo nas diversas áreas de política pública [...]. Mais do que isso, estudar a fase de implementação também significa visualizar erros anteriores à tomada de decisão, a fim de detectar problemas mal formulados, objetivos mal traçados, otimismos exagerados. ${ }^{35}$

Assim, a fase de implementação costuma ocorrer simultaneamente à fase de monitoramento.

f- $\quad$ Monitoramento

Quanto à significação desta fase, Rua expõe o seguinte entendimento:

[...] um conjunto de procedimentos de apreciação dos processos adotados, dos resultados preliminares e intermediários obtidos e do comportamento do ambiente da política. $\mathrm{O}$ monitoramento é um instrumento de gestão das políticas públicas e o seu objetivo é facilitar a consecução dos objetivos pretendidos com a política [...].36

O monitoramento constitui, assim, fase de acompanhamento das ações implementadas objetivando adequar as ações aos resultados previstos no inicio do ciclo.

\footnotetext{
${ }^{33} \mathrm{Ibid}$.

${ }^{34}$ RUA, op. cit.

${ }^{35}$ SECCHI, op. cit., p. 45.

${ }^{36}$ RUA, op. cit., p. 38 .
} 
Secchi, considera que o monitoramento constitui fase de avaliação, mais especificamente, avaliação formativa ou in intinere, que acontece durante o processo de implementação objetivando ajustamentos imediatos. ${ }^{37}$

\section{g- Avaliação}

Segundo o entendimento de Rua esta fase constitui-se de procedimentos de julgamento dos resultados de uma política, de acordo com critérios que expressam valores e, com o monitoramento fornece embasamento a novas decisões para aperfeiçoamento das ações implementadas. ${ }^{38}$

Nesta fase são estabelecidos critérios, padrões e indicadores para auxílio na formação de um juízo crítico dos resultados das ações implementadas, permitindo, desta maneira, a realização de atuações mais adequadas à resolução da demanda social que gerou o ciclo da política pública em questão.

Secchi assevera que cinco são os principais critérios de avaliação:

-Economicidade: refere-se ao nível de utilização de recursos (inputs).

-Eficiência econômica: trata de relação entre inputs (recursos utilizados) e outputs (produtividade).

-Eficiência administrativa: trata dos segmentos de prescrições, ou seja, do nível de conformação da execução a métodos preestabelecidos.

-Eficácia: corresponde ao nível de alcance de metas ou objetivos preestabelecidos.

.-Equidade: trata da homogeneidade de distribuição de benefícios (ou punições) entre os destinatários de uma política pública. ${ }^{39}$

Estes critérios auxiliarão no estabelecimento do nível de satisfação gerado por uma política pública no contexto social a que se destina e possíveis formas de aperfeiçoamento do ciclo de políticas públicas.

h- Ajuste

Consiste na aplicação de ações corretivas do processo de formulação das políticas públicas buscando otimizar recursos a fim de, efetivamente, alcançar os resultados definidos como imprescindíveis para as mudanças necessárias no contexto social.

As fases do ciclo de políticas públicas até aqui analisadas nem sempre são subsequentes, podendo ocorrer simultaneamente devido às diversas peculiaridades e complexidades do contexto social moderno. Certo é que os impactos gerados pela política pública como um todo efetivar-se-ão a longo prazo.

Esboçados os aspectos técnicos que envolvem as etapas de implementação, controle e ajustes de políticas públicas, é importante ressaltar, neste passo, que o cumprimento de todas essas etapas, suscintamente apresentadas acima, envolve a presença do que se convencionou chamar no senso comum de "vontade política”.

\footnotetext{
${ }^{37}$ SECCHI, op. cit.

${ }^{38}$ RUA, op. cit.

${ }^{39}$ SECCHI, op. cit., p. 50.
} 
Decerto que uma abordagem meramente tecnicista, que parta de uma suposta neutralidade nas escolhas efetuadas, com ampla margem discricionária para eleição de objetivos, métodos de implementação, controle e ajustes, não se coadunam com o sentido aqui perseguido.

Em outros termos, as políticas públicas tendentes à concretização dos direitos fundamentais sociais devem ter como parâmetro a realização dos objetivos fundamentais da República, não podendo se subordinar às agendas políticas dos detentores do poder, por mais legítimas que se afeiçoem.

Nesta altura, uma vez delimitados os contornos das políticas públicas, e reafirmada sua relação teleológica com os direitos fundamentais, vejamos como se dá tal relação.

\section{POLÍTICAS PÚBLICAS E DIREITOS FUNDAMENTAIS}

\section{Da Nota de Fundamentalidade dos direitos}

O primeiro problema com que nos deparamos na tentativa de delimitar a nota de fundamentalidade de determinados direitos é a constatação de que o termo Direitos Fundamentais não tem sido utilizado de forma unívoca.

Ingo Sarlet alerta para a ausência de consenso na esfera conceitual e terminológica sobre a expressão, confusão reproduzida inclusive no texto constitucional de 1988, ao aludir a termos diversos quando se refere aos direitos fundamentais. ${ }^{40}$

A polêmica não é ociosa, pois a partir da compreensão da existência ou não de direitos tidos como fundamentais, sua delimitação, sua inerência, a (im)possibilidade de dissociação de um determinado ordenamento, sua relação com os interesses, posições jurídicas e direitos subjetivos, e as respectivas consequências jurídicas de seu reconhecimento, é que podemos nos posicionar e desenvolver um esboço do que seriam os direitos fundamentais subjetivos e sua relação com as políticas públicas, noções essenciais para o escopo do presente trabalho.

A primeira questão a ser enfrentada, na busca da correta delimitação conceitual, diz com a diferenciação do termo em relação a outros termos largamente utilizados, tais como: Direitos Humanos, Direitos Naturais, Direitos Individuais, Direitos do Homem, Direitos Públicos Subjetivos, Liberdades Fundamentais, Liberdades Públicas, entre outros.

José Afonso da Silva, inspirado em Peres Luño, após traçar um quadro diferenciador entre os variados termos utilizados, elege a expressão Direitos Fundamentais do Homem, qualificando-a como a mais adequada, pois, segundo ele:

${ }^{40}$ SARLET, Ingo Wolfgang. A eficácia dos direitos fundamentais. Porto Alegre: Livraria do Advogado, 2007. 
[...] além de referir-se a princípios que resumem a concepção do mundo e informam a ideologia política de cada ordenamento jurídico, é reservada para designar, no nível do direito positivo, aquelas prerrogativas e instituições que ele concretiza em garantias de uma convivência digna, livre e igual de todas as pessoas". ${ }^{41}$

Para ele, a nota de fundamentalidade encontra-se:

[...] na indicação de que se trata de situações jurídicas sem as quais a pessoa humana não se realiza, não convive e, às vezes, nem mesmo sobrevive; fundamentais do homem no sentido de que a todos, por igual, devem ser, não apenas formalmente reconhecidos, mas concreta e materialmente efetivados. ${ }^{42}$

Luigi Ferrajoli, adotando uma concepção formal dos direitos fundamentais, contrapondo-os ao que denomina de direitos patrimoniais, dissocia a fundamentalidade dos direitos de qualquer ordenamento jurídico específico:

[...] sono 'diritti fondamentali' tutti quei diritti soggettivi che spettano universalmente a 'tutti' gli esseri umani in quanto dotati dello status di persone, o di cittadini o di persone capaci d'agire; inteso per 'diritto soggettivo' qualunque aspettativa positiva (a prestazioni) o negativa (a non lesioni) ascritta ad un soggetto da una norma giuridica, e per 'status' la condizione di un soggetto prevista anch'essa da una norma giuridica positiva quale presupposto della sua idoneità ad essere titolare di situazioni giuridiche e/o autore degli atti che ne sono esercizio. ${ }^{43}$

Em sentido oposto, também com lastro em Pérez Luño, Ingo Sarlet defende a indissociabilidade entre direitos fundamentais e uma dada ordem jurídica. ${ }^{44}$

Segundo sustenta, os direitos fundamentais constituiriam o conjunto de direitos e liberdades institucionalmente reconhecidos e garantidos pelo ordenamento de um determinado Estado, perfeitamente delimitado espacial e temporalmente.

Para ele, a nota de fundamentalidade residiria no caráter básico e fundamentador de todo o sistema jurídico.

Haveria, assim, uma indissociabilidade entre direitos fundamentais e constituição.

Cesar Peluso sustenta o caráter supralegal dos Direitos Fundamentais. Para ele, a nota de fundamentalidade dos direitos estaria relacionada precipuamente ao reconhecimento e valorização da dignidade humana e à qualidade específica, formal e material, observada na tessitura de tais direitos. ${ }^{45}$

\footnotetext{
${ }^{41}$ SILVA, José Afonso. Curso de direito constitucional positivo. 22. ed. São Paulo: Malheiros, 2003, p. 178.

${ }^{42}$ Ibid., p. 178.

${ }^{43}$ FERRAJOLI, L. Diritti Fondamentali - Un dibattito teórico. A cura di E. Vitale. Roma: Libri del Tempo, 2008, p. 5. "São 'direitos fundamentais' todos aqueles direitos que pertencem universalmente a todos os seres humanos, uma vez que têm o estatuto de pessoas, de cidadãos ou pessoas capazes de agir; entendido direito subjetivo como "qualquer expectativa positiva (a prestação) ou negativa (não lesão) atribuída a uma pessoa como um estado de Direito, e por 'status' a condição de um sujeito derivada de uma regra positiva de direito como condição da sua aptidão para ser titular de situações jurídicas e / ou autor dos atos que são exercidos".

${ }^{44}$ SARLET, Ingo Wolfgang. A eficácia dos direitos fundamentais. Porto Alegre: Livraria do Advogado, 2007, p. 37-38.

${ }^{45}$ PELUSO, Cesar. Direitos fundamentais: conceito, eficácia e perspectiva. Palestra proferida em 20/05/2013, durante o Curso de Aperfeiçoamento São Paulo: Fundação Armando Álvares Penteado, 2013.
} 
A revelar tais características, o ex-ministro do Supremo Tribunal Federal ressalta, entre outros, o fato da inalterabilidade dos Direitos Fundamentais (cláusulas pétreas), sua aplicabilidade imediata e a observação de regime jurídico especial.

Robert Alexy, investigando a teoria dos direitos fundamentais na ordem jurídica alemã, assinala que em uma teoria dogmática da estrutura dos direitos fundamentais pode-se distinguir três dimensões: uma analítica, uma empírica e uma normativa. ${ }^{46}$

A dimensão analítica diria com a "dissecção sistemático-conceitual do direito vigente" empírica envolveria tanto a cognição do direito positivo válido, quanto a aplicação de premissas empíricas na argumentação jurídica; e a dimensão normativa atinaria à "elucidação e à crítica da práxis jurídica, sobretudo da práxis jurisprudencial? ${ }^{48}$

Para ele, a elaboração de uma teoria geral dos direitos fundamentais expressaria um ideal teórico, reclamando a adoção de uma teoria integradora "a qual engloba, da forma mais ampla possível, os enunciados gerais, verdadeiros ou corretos, passiveis de serem formulados no âmbito das três dimensões e os combine de forma otimizada" ${ }^{49}$

Alexy refuta, assim, as teorias sobre direitos fundamentais tidas como "unipolares" elaboradas sob a forma de concepções básicas e que reduzem os direitos fundamentais a uma tese vinculada a uma só concepção.

Segundo entende, dada a complexidade e multiplicidade da matéria regulada pelos direitos fundamentais, há uma impossibilidade de redução a um único princípio, exceto àqueles de elevadíssimo grau de abstração, como o que estabelece que o fim último dos direitos fundamentais é a garantia da dignidade humana.

Refuta ainda, a adoção de teorias combinadas, com a adoção de referenciais pertencentes às diversas teorias unipolares existentes, ressaltando que "Contra uma teoria combinada levanta-se de imediato a objeção de que ela não é uma teoria que possa guiar a decisão e fundamentação jurídicas, mas apenas uma coleção de topoi extremamente abstratos, dos quais se pode servir da maneira que se desejar". ${ }^{50}$

Ausente, portanto, em tal abordagem dos direitos fundamentais, o caráter sistemático exigível em uma teoria abrangente dos direitos fundamentais.

Proclamando, assim, a insuficiência das teorias unipolares e combinadas, Alexy propõe a elaboração de modelo que ultrapasse a simples compilação não vinculativa das diversas teorias unipolares, tarefa que, segundo ele, incumbiria a uma teoria integrativa dos direitos fundamentais.

\footnotetext{
${ }^{46}$ ALEXY, Robert. Teoria dos direitos fundamentais. 2.ed. São Paulo: Malheiros, 2012.

${ }^{47}$ Ibid., p. 33-35.

${ }^{48} \mathrm{Ibid}, \mathrm{p} .33-35$.

${ }^{49}$ Ibid. p. 39.

${ }^{50}$ Ibid. p. 42.
} 
Uma teoria integrativa dos direitos fundamentais, na visão de Alexy, "passa por uma teoria estrutural dos direitos fundamentais.".

A teoria estrutural proposta por Alexy, embora não se resuma a esse viés, parte de uma abordagem analítica da estrutura lógico-formal dos direitos fundamentais na ordem jurídica alemã. Para tanto, defende a estreita conexão entre o conceito de norma de direito fundamental e o próprio conceito de direito fundamental.

Neste ponto, a questão que se afiguraria relevante seria a relação existente entre direitos subjetivos e direitos fundamentais, dada a possibilidade teórica de existência de normas de direitos fundamentais que não corresponderiam diretamente a nenhum direito subjetivo outorgado.

Assim, no entendimento de Alexy, o conceito de norma de direito fundamental seria mais amplo que o próprio conceito de direitos fundamentais e a existência de um direito fundamental teria como pressuposto a existência e validade de uma norma correspondente, pelo que justificar-se-ia a análise do conceito de direito fundamental, a partir da análise do conceito de norma de direito fundamental.

O problema é que o conceito de norma na ciência jurídica também não encontra interpretação unívoca, exigindo que se situe o ponto de referência utilizado para a construção da teoria estrutural dos direitos fundamentais. Neste sentido, Alexy destaca a diferença entre norma e enunciado normativo, sendo a primeira o conceito primário de onde pode decorrer um ou mais enunciados normativos.

Isto porque há casos de normas com possibilidade de um ou mais enunciados normativos e há até mesmo normas sem enunciados normativos. Daí a importância de "os critérios para identificação de normas sejam buscados no nível da norma e não do enunciado normativo". ${ }^{2}$

A busca de tais critérios é facilitada pelo auxílio das modalidades deônticas (dentre outras, a do dever, da proibição e da permissão).

Decerto que a utilização de operadores deônticos afivela-se a uma análise semântica da norma jurídica, entretanto, a análise semântica não dá conta das questões referentes à existência e validade da norma.

Com efeito, Alexy sustenta que o conceito de norma, a priori, deve ser desvinculado dos pressupostos de existência e validade da norma, observando-se o viés semântico.

Conforme predito, Alexy cinge sua análise da teoria da norma de direitos fundamentais ao ordenamento jurídico alemão, pelo que define, em uma primeira aproximação, as normas de direitos fundamentais como sendo aquelas que são expressas diretamente por enunciados da Constituição alemã e mais aquelas "normas atribuídas" que, a despeito de não integrarem diretamente o catálogo das normas explicitamente qualificadas como de direitos fundamentais, permitem uma correta fundamentação referida a direitos fundamentais.

\footnotetext{
${ }^{51}$ ALEXY, op. cit., p. 42.

${ }^{52}$ Ibid. p. 54.
} 
Todo esse desenvolvimento da teoria da norma em Alexy, desagua na consagrada sistematização elaborada por ele, ao distinguir regras e princípios.

A distinção entre regras e princípios é tida por ele como "a base da teoria da fundamentação no âmbito dos direitos fundamentais e uma chave para a solução de problemas centrais da dogmática dos direitos fundamentais" ${ }^{53}$, sendo uma das "colunas-mestras do edificio da teoria dos direitos fundamentais" . ${ }^{54}$

Com efeito, a ideia de norma abrangeria tanto regras como princípios, isto porque ambos atinem ao dever-ser, podem ser reduzidos aos operadores deônticos básicos do dever, da proibição e da permissão. Princípios e regras, portanto, seriam duas espécies de normas.

Segundo Alexy, princípios seriam "mandamentos de otimização", constituindo-se em "normas que ordenam que algo seja realizado na maior medida possivel dentro das possibilidades jurídicas e fáticas existentes" ${ }^{55}$

Assim, os princípios admitiriam a satisfação do enunciado normativo nele expresso em diversos graus, a partir de dois limitadores: as possibilidades fáticas e as possibilidades jurídicas. No que tange às possibilidades jurídicas estas seriam delimitadas pelos conflitos entre princípios e regras colidentes.

Neste ponto, devemos constatar que um maior desenvolvimento da teoria dos direitos fundamentais de Alexy, embora interessante, desvirtuaria o escopo do presente trabalho, restando assentado que o ponto de observação aqui adotado em relação à nota de fundamentalidade dos direitos ancora-se em dois pressupostos: a indissociabilidade dos direitos fundamentais a uma determinada ordem jurídica e, em grau máximo de abstração, sua indelével relação com a satisfação e garantia da dignidade pessoa humana.

Dito isto, veremos, em seguida, a relação entre direitos fundamentais, políticas públicas e planejamento.

\section{Políticas Públicas e concretização dos Direitos Fundamentais}

\section{A Constituição Federal de 1988 trouxe um amplo catálogo de direitos fundamentais.}

Transcorridos mais de vinte anos de sua promulgação, constata-se ainda uma grande dificuldade em se estabelecer uma ponte de ligação sobre o abismo existente entre o conteúdo dos enunciados normativos que determinam posições jurídicas e, ou, relações obrigacionais, tendo por sujeito passivo o Estado, e a sua concreta realização no mundo dos fatos.

Embora se revele um truísmo afirmar que as políticas públicas constituem um instrumento privilegiado para a materialização dos direitos fundamentais, a constatação do descompasso existente entre os enunciados normativos de direitos fundamentais e sua efetiva realização, especialmente consideradas as sempre objetadas

\footnotetext{
${ }^{53}$ ALEXY, op. cit., p.84.

${ }^{54}$ Ibid. p. 84 .

${ }^{55}$ Ibid., p. 90.
} 
limitações fáticas e jurídicas, aponta para a necessidade de voltarmos nossa atenção para este instrumento de gestão e planejamento que pode estabelecer uma verdadeira ponte na superação desse abismo entre os mundos do ser e do dever-ser.

Segundo SARLET, os direitos fundamentais constituem parâmetro hermenêutico e valores superiores de toda ordem constitucional, havendo nítida distinção entre destinatários e titulares de direitos fundamentais. ${ }^{56}$

Referindo-se à perspectiva jurídico-objetiva dos direitos fundamentais, SARLET assinala dois aspectos relevantes para a compreensão da eficácia de tais direitos ${ }^{57}$. O primeiro seria:

[...] a inexistência de um paralelismo necessário entre regras e a perspectiva subjetiva e, por outro lado, entre princípios e perspectiva objetiva, de tal sorte que se pode falar em regras e princípios consagradores de direitos subjetivos fundamentais, bem como de regras e

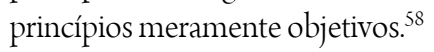

O segundo aspecto diria com a distinção entre significação da perspectiva objetiva como expressão de uma ordem de valores fundamentais objetivos e o reconhecimento de efeitos jurídicos autônomos, para além da perspectiva subjetiva. $^{59}$

Neste sentido, deve-se considerar que as avaliações sobre a efetividade dos direitos fundamentais (especialmente os de índole prestacional) e, especificamente, sobre sua exigibilidade, tem desaguado, invariavelmente, em uma taxionomia das normas constitucionais, com classificações, embora divergentes, muito assemelhadas no que tange à eficácia de tais normas.

O ângulo de aproximação aqui proposto é diverso. Partimos da noção de dever estatal e correspectivo direito público subjetivo ao planejamento. Afirma-se, como ponto de partida, a existência de um direito fundamental ao planejamento.

As políticas públicas como instrumentos de planejamento constituem modalidade de intervenção do Estado no domínio econômico, já que, para realização dos objetivos fundamentais da República, o Estado deve planejar sua atuação.

Há, assim, sob o enfoque jurídico, um dever fundamental e um correspondente direito público subjetivo, à implementação de políticas públicas tendentes à concretização dos direitos fundamentais sociais, tornando-o exigivel em casos de ausência, insuficiência ou ineficácia de tais políticas.

Decerto que tal constatação não representa qualquer novidade, nem resolve a questão das variáveis essenciais de qualquer política pública, quais sejam: aquelas relacionadas à discricionariedade na definição dos objetivos, na escolha dos meios e na hierarquização de prioridades.

\footnotetext{
${ }^{56}$ SARLET, op. cit., p.77.

${ }^{57}$ Embora o autor refira-se, no corpo do texto, a três aspectos relevantes, o último deles tem natureza metodológica, relacionado à forma de abordagem do tema, pelo que não o mencionaremos.

${ }^{58}$ SARLET, op. cit., p. 161.

${ }^{59} \mathrm{Ibid}, \mathrm{p} .161$.
} 
Entretanto, traz em si uma significativa mensagem subliminar: a vedação à inércia e a proibição da insuficiência. Em outros termos, afirma-se que à efetivação de direitos fundamentais, e com mais razão os direitos sociais, de índole prestacional, não pode ser oposta a exceção de escassez e, ou, finitude de recursos como justificativa para a ausência ou insuficiência de planejamento.

A obrigatoriedade de planejamento foi bem sintetizada por Adilson Abreu Dallari, que ressalta a mudança operada com a Constituição-Cidadã de 1988 e com o Estatuto da Cidade de 2001:

O planejamento, antes de conquistar status de regra jurídica, ganhou a adesão de teóricos da Ciência da Administração e da Economia. Em especial no campo urbanístico, a ação de planejar foi considerada indispensável ao crescimento racional e ordenado das cidades. Repetia-se, como regra inquestionável, a necessidade de planejamento urbano. Tal regra, todavia, no início tinha caráter exclusivamente metajurídico. Tratava-se de uma proposição da Ciência da Administração, do Urbanismo. Não era dotada de juridicidade - vale dizer, seu descumprimento não demandava a aplicação de sanções jurídicas. A adoção do planejamento urbano, concretizado geralmente num plano diretor (às vezes aprovado por lei, outras vezes por mera decisão administrativa), dependia exclusivamente de uma avaliação de natureza política-administrativa. Assim, diversos Municípios editaram plano diretor sem que houvesse, contudo, obrigatoriedade de fazê-lo, ou mesmo, a fixação de qualquer padrão que estabelecesse um conteúdo mínimo a ser atendido pela planificação. A existência de um plano diretor era exigência que se punha no campo da ciência da Administração Urbana, que somente adquiria contornos jurídicos se e quando fosse E prossegue: encampada na regulamentação (legal ou infralegal) de um dado Município. ${ }^{60}$

Essa fase começou a mudar com a Constituição Federal de 1988. Na atual Carta Magna, a técnica do planejamento urbano foi consagrada normativamente, sendo eleito o caminho de implementação da política de desenvolvimento urbano (art. 182, caput). O plano diretor foi qualificado como principal instrumento de implementação de uma política de desenvolvimento e expansão urbana $\left(\operatorname{art} .182, \$ 1^{\circ}\right) .{ }^{61}$

Como visto, exemplificativamente, no campo do Direito Urbanístico, a obrigatoriedade de planejamento, nos termos da Constituição Federal, deixa de ter como critério exclusivo as avaliações dos técnicos e a simples ponderação da conveniência política do governante em exercício, devendo conformar-se, antes, aos objetivos maiores perseguidos pela República. ${ }^{62}$

Assim, as políticas públicas, como instrumento de viabilização do atendimento dos objetivos maiores da República, não podem, por óbvio, confrontar ou negligenciar tais objetivos e fundamentos.

A Constituição Federal de 1988, no art. $165^{63}$, determina a obrigatoriedade do planejamento para o setor público. No mesmo sentido, o conteúdo do art. $174^{64}$, topologicamente situado no capítulo que trata dos princípios gerais da atividade econômica.

\footnotetext{
${ }^{60}$ DALLARI, Adilson Abreu; FERRAZ, Sérgio (Org.) Estatuto da Cidade: comentários à Lei Federal 10.257/2001. 2. ed. São Paulo: Malheiros, 2006, p. 319.

${ }^{61}$ Ibid., p. 319.

${ }^{62} \mathrm{Ibid}$.

${ }^{63}$ Art. 165. Leis de iniciativa do Poder Executivo estabelecerão:

I- o plano plurianual;
} 
Decerto que a obrigatoriedade do planejamento, presente em diversos tópicos dispersos na Carta Política ${ }^{65}$, deriva, no plano fático, da necessidade de racionalização da atividade pública no que tange aos recursos e meios utilizados para atingimento dos objetivos fundamentais da República. É certo ainda que o planejamento orienta as atividades materiais da Administração, em sentido prospectivo, com vistas à satisfação e garantia da dignidade humana, epicentro axiológico de toda ordem jurídica. ${ }^{66}$

Pode-se verificar, portanto, a nota de fundamentalidade do direito ao planejamento, sendo este obrigatório para o setor público e indicativo para o setor privado.

Não se pode ignorar, por óbvio, que toda política pública encarta em si uma compreensão da realidade, permeada por uma lente ideologizada e por uma concepção normativa de democracia. Em outros termos, pode-se afirmar que não há neutralidade na escolha dos objetivos e na adoção de modelos procedimentais que, em primeira e última instância são determinantes no processo de planejamento e na elaboração, implementação, monitoramento e avaliação das políticas públicas.

A questão assume relevo se considerarmos que o processo de participação na produção e implementação das políticas públicas é decisivo não só na escolha discricionária dos objetivos a alcançar, nos meios e na hierarquização de prioridades, mas também pode moldar o próprio resultado a ser alcançado ou negligenciado pelo processo de planejamento.

A elaboração e implementação de políticas públicas concretizadoras de direitos fundamentais não se insere, portanto, na atividade discricionária da administração, constituindo um dever fundamental do Estado explicitar os meios com que pretende atingir os fins delimitados pela Carta Política, havendo vedação à conduta omissiva ou à insuficiência dos meios, conforme veremos no tópico que se segue.

\section{Da vedação à inércia e à insuficiência das políticas públicas}

Conforme sustentado até aqui, há um direito fundamental e correspectivo dever estatal de planejamento. O objeto de tal obrigação corresponderia a uma ação normativa do Estado consistente em elaborar planos, programas, projetos e políticas públicas tendentes a concretizar os objetivos fundamentais da República.

\footnotetext{
II - as diretrizes orçamentárias;

III - os orçamentos anuais.

[...].

${ }^{64}$ Art. 174. Como agente normativo e regulador da atividade econômica, o Estado exercerá, na forma da lei, as funções de fiscalização, incentivo e planejamento, sendo este determinante para o setor público e indicativo para o setor privado.

${ }^{65}$ Como, por exemplo, nos artigos 26, $\$ 3^{\circ}$; 30, VIII; 43, \$1 ${ }^{\circ}$, II; 48, II e IV; 187; etc.

${ }^{66}$ BERNARD, Wesley de Oliveira Louzada. O princípio da dignidade da pessoa humana e o novo direito civil: breves reflexões. Revista da Faculdade de Direito de Campos, ano VII, n. 8, jun. 2006, p. 243.
} 
Assim, embora possa se questionar a exigibilidade dos direitos fundamentais subjetivos de índole prestacional ${ }^{67}$, em espécie, em face das limitações fáticas e jurídicas sempre opostas, torna-se inquestionável a exigibilidade das atividades de planejamento para, conforme o caso, mitigação ou eliminação do déficit social diagnosticado.

A título exemplificativo, podemos mencionar o direito social fundamental à moradia, consagrado no caput do art. $6^{\circ}$ da Constituição Federal. É consenso que a previsão constitucional contida no mencionado dispositivo não outorga, por si só, o direito subjetivo a cada cidadão de ver atendido seu pleito habitacional de forma imediata, dadas as limitações econômicas e financeiras do Estado. Entretanto, a atividade de planejamento permite, de forma bastante precisa e consistente, diagnosticar o déficit habitacional quantitativo e qualitativo e projetar soluções para mitigação ou eliminação de tal déficit em determinado espaço temporal.

Portanto, há uma mudança do foco de exigibilidade dos direitos fundamentais prestacionais do objeto em si para os instrumentos que permitirão a concretização deste direito a algo.

Como já dito, ao direito a algo aplicam-se os operadores deônticos relacionados aos conceitos básicos de dever, proibição e permissão.

A Constituição Federal de 1988 definiu como obrigatória (dever) a atividade de planejamento, sendo as políticas públicas, os programas e projetos ferramentas de concreção da atividade planejadora.

A despeito de não integrar diretamente o catálogo das normas explicitamente qualificadas como de direitos fundamentais, não pendem dúvidas sobre a nota de fundamentalidade de tal direito, mormente quando intrinsecamente relacionado ao cumprimento dos objetivos fundamentais da República. ${ }^{68}$

A inobservância ou menoscabo ao princípio do planejamento tem se constituído em fonte determinante para sonegação dos direitos fundamentais sociais.

Não obstante a demonstração da relação indissociável entre políticas públicas e realização dos objetivos fundamentais da República, tarefa indelegável dos detentores do poder, tal relação tem sido ignorada nos casos de ausência ou insuficiência de políticas públicas.

A diversidade de espécies e a complexidade na implementação das políticas públicas constituem fontes adicionais de geração de conflitos sociais que, no mais das vezes, vão terminar nas portas do Judiciário, engendrando a judicialização das políticas.

\footnotetext{
${ }^{67}$ Observe-se que não só os direitos sociais tidos por prestacionais envolvem custos. Muitos direitos de liberdade também demandam altíssimos custos, como a manutenção da própria estrutura do Estado para garantir o Direito de ir e vir, as eleições, o sistema eleitoral, o sistema penal, entre outros. Assim, a limitação econômica ou financeira não deve ser tida como fator determinante para negação dos direitos sociais, mas sim o caráter subalterno que tem assumido até o presente.

${ }^{68}$ Art. $3^{\circ}$ Constituem objetivos fundamentais da República Federativa do Brasil: I - construir uma sociedade livre, justa e solidária; II - garantir o desenvolvimento nacional; III - erradicar a pobreza e a marginalização e reduzir as desigualdades sociais e regionais; IV promover o bem de todos, sem preconceitos de origem, raça, sexo, cor, idade e quaisquer outras formas de discriminação. vol.07, nº. 02, Rio de Janeiro, 2014. pp. 617-657 
A exigibilidade de planejamento tem como correspondente lógico a vedação à inércia. Se conjugarmos tais princípios com o princípio constitucional da eficiência (art. 37, caput), percebemos claramente a vedação constitucional à insuficiência do planejamento.

Deste modo, pode-se afirmar um direito subjetivo fundamental a um planejamento eficiente, com vedação à inércia e à insuficiência das políticas públicas tendentes à concretização dos direitos fundamentais sociais.

Como se sabe, em nível de macrogestão, o planejamento da atuação estatal materializa-se, precipuamente, nos Planos Plurianuais, nas Diretrizes Orçamentárias e nos Orçamentos Anuais.

A análise de tais instrumentos políticos-jurídicos torna-se essencial para o controle da concretização dos direitos fundamentais sociais.

Não se ignora que há um grande abismo entre as metas estabelecidas nos planos governamentais e o seu efetivo cumprimento.

Neste sentido, Américo Bedê Freire Junior, discorrendo sobre o controle judicial de políticas públicas e a reserva do possível, assinala que:

Há outras questões interessantes relacionadas ao problema da reserva do possível no seu aspecto jurídico, como, por exemplo: (a) política pública prevista no plano plurianual, mas não prevista na lei orçamentária; (b) política pública prevista no plano plurianual, não realizada a despesa até o fim do exercício em curso; (c) política pública prevista no plano plurianual, com dotação orçamentária na lei orçamentária anual, porém realizada apenas em parte no exercício próprio; (d) possibilidade de o juiz determinar a inclusão de política pública no próprio plano plurianual; (e) problema de que a previsão na lei orçamentária anual não gera direitos subjetivos, nem obriga o administrador a realizar a despesa prevista; (f) política pública prevista no plano plurianual, com dotação orçamentária na lei orçamentária anual, mas ainda não efetivada. ${ }^{69}$

$\mathrm{O}$ fato de se reconhecer que o estabelecimento de objetivos e metas nos PPA's ou a simples previsão orçamentária, não garantem, por si sós, a realização da entrega efetiva do bem da vida perseguido por tais enunciados, não retira a importância do monitoramento ou avaliação das políticas públicas, através da análise dos principais instrumentos de planejamento, conforme veremos nos tópicos que se seguem.

\section{ORÇAMENTO E PARTICIPAÇÃO POPULAR}

Passados os estudos acerca das políticas públicas e da importância de planejamento, far-se-á uma breve abordagem teórica dos conceitos de orçamento público e de mecanismos de participação popular no sentido de se efetivar tais políticas em prol da coletividade, especialmente o denominado orçamento participativo, cujas experiências efetivas se deram após a Constituição Cidadã de 1988.

Segundo Aliomar Baleeiro:

${ }^{69}$ FREIRE JUNIOR, Américo Bedê. O controle judicial de políticas públicas. São Paulo: Revista dos Tribunais, 2005, pp. 76-77 vol.07, nº. 02, Rio de Janeiro, 2014.pp. 617-657 
Orçamento Público é o ato pelo qual o Poder Legislativo autoriza o Poder Executivo por um certo período e, em pormenor, às despesas destinadas ao funcionamento dos serviços públicos e outros fins adotados pela política econômica do País, assim como a arrecadação das receitas criadas em lei. ${ }^{70}$

Em artigo denominado Orçamento Público e gestão governamental, Moisés Francisco Farah Júnior conceitua: "O orçamento público, em sentido amplo, é um documento legal (aprovado por lei) contendo a previsão de receitas e a estimativa de despesas a serem realizadas por um governo em um determinado exercício (geralmente um ano)"? ${ }^{\prime 1}$

Por sua vez, para Machado Júnior "O orçamento é um plano de trabalho, expresso em termos financeiros, para um determinado período de tempo, contendo os meios de financiamento das despesas governamentais e aprovado por uma lei."72

Esta definição, segundo o autor, permite definir o orçamento como instrumento de planejamento; conceber o plano em termos financeiros; manter o aspecto legal do orçamento; limitar, no tempo e nas dotações, a autorização legislativa para a arrecadação da receita e aplicação dos dinheiros.

Para atingir o bem comum, objetivo primordial da Administração, existem três funções orçamentárias clássicas, a saber: função alocativa, função distributiva e a função estabilizadora.

Alocativa é uma provisão, um pagamento de bens e serviços públicos com fundos do erário, sem que necessariamente eles sejam produzidos pelo governo, conforme James Giacomoni. ${ }^{73}$

Augustinho Paludo, acerca de tal função, leciona:

[...] relaciona-se à alocação de recursos por parte do Governo, a fim de oferecer bens e serviços públicos puros (ex. rodovias, segurança, justiça) que não seriam oferecidos pelo mercado ou seriam em condições ineficientes; bens meritórios ou semipúblicos (ex. educação e saúde); e criar condições para que os bens privados sejam oferecidos no mercado pelos produtores, corrigir imperfeições no sistema de mercado (como oligopólios) e corrigir os efeitos negativos de externalidades. ${ }^{74}$

A função distributiva, também segundo Paludo:

[...] visa tornar a sociedade menos desigual em termos de renda e riqueza, através da tributação e de transferências financeiras, subsídios, incentivos fiscais, alocação de recursos em camadas mais pobres da população. ${ }^{75}$

Ele cita como exemplos os programas Fome Zero, Bolsa Família e a destinação de recursos para o Sistema Único de Saúde - SUS, utilizado por indivíduos de menor renda.

\footnotetext{
${ }^{70}$ BALEEIRO, Aliomar. Uma Introdução à Ciência das Finanças. 9. ed. Rio de Janeiro: Forense: 1973. p. 397.

${ }^{71}$ FARAH JUNIOR, Moisés F. Orçamento público e gestão governamental. In: SILVA, Christian Luiz da (Org.) Políticas Públicas e Desenvolvimento Local. Instrumentos e proposições de análise para o Brasil. Petrópolis: Vozes, 2012, Cap.2, p. 43.

${ }^{72}$ MACHADO JUNIOR, José Teixeira. Racionalização da Elaboração Orçamentária através do Orçamento-Programa. IBAM: Mímeo, 2011, p. 02.

${ }^{73}$ GIACOMONI, James. Orçamento Público. São Paulo: Atlas, 2010.

${ }^{74}$ PALUDO, Augustinho. Orçamento Público, Administração Financeira e Orçamentária e Lei de Responsabilidade Fiscal. 3. ed. Rio de Janeiro: Elsevier, 2012, p. 05.

${ }^{75}$ Ibid., p. 05.
} 
Giacomoni apresenta alguns mecanismos para financiar essa função alocativa, tais como a instituição do imposto de renda progressivo, onde a alíquota aumentaria em consonância ao crescimento da renda; uma das funções extrafiscais do tributo de concessão de benefícios fiscais a produtos populares e de maior necessidade em contrapartida ao aumento de alíquotas a produtos consumidos pelas classes de renda mais alta ou supérfluos; além de medidas públicas em sentido mais amplo como a disponibilização de educação gratuita, capacitação profissional e os programas de desenvolvimento comunitário. ${ }^{76}$

Já a função orçamentária estabilizadora, considerada por Giacomoni como a mais moderna das três:

[...] além do ajustamentos na alocação de recursos e na distribuição de renda a política fiscal tem quatro objetivos macroeconômicos: manutenção de elevado nível de emprego, estabilidade nos níveis de preços, equilibrio no balanço de pagamentos e razoável taxa de crescimento econômico. ${ }^{77}$

Além disso, dadas as várias nuances do orçamento, a exemplo de políticas; jurídicas; contábeis; econômicas; financeiras e administrativas, a forma mais simples de entendê-lo é dividir a evolução de seus conceitos historicamente, donde se extraem duas fases, a saber: aquela do orçamento tradicional e a do moderno. $^{78}$

O tradicional surgiu por volta de 1822, na Inglaterra, tendo como principal objetivo o controle político, dado o clamor pelo controle dos gastos públicos, então em voga pelas premissas do liberalismo econômico ora evidente. Seu foco era o gasto realizado sem qualquer preocupação com o planejamento, com a intervenção na economia ou com o bem estar da população.

O mesmo autor frisa que:

[...] o aspecto econômico tinha posição secundária. As finanças públicas caracterizavam-se por sua "neutralidade": o equilibrio financeiro impunha-se naturalmente e o volume do gasto público não chegava a pesar significativamente em termos econômicos. ${ }^{79}$

Já o orçamento moderno tem como diretriz ser um instrumento de administração, auxiliando os gestores públicos nas etapas do processo administrativo: programação, execução e controle.

Após algumas iniciativas pioneiras de buscar esse objetivo, evoluindo assim aquela forma tradicional, a exemplo do PPBS - Planning Programming and Budgetin System (Sistema de Planejamento, Programação e Orçamento), chegou-se ao que hoje é denominado de Orçamento de Desempenho, em que a ênfase no desempenho organizacional e na avaliação dos resultados passa a serem elementos indissociáveis, apresentando duas dimensões, de forma que "o objeto do gasto e um programa de trabalho, contendo as açôes desenvolvidas"."

\footnotetext{
${ }^{76}$ GIACOMONI, op. cit., p. 25.

${ }^{77}$ Ibid., p. 26.

${ }^{78}$ GIACOMONI, op. cit., p.54.

${ }^{79}$ Ibid. p. 55.

${ }^{80}$ PALUDO, op. cit., p. 08.
} 
Nesse sentido, mais uma vez remete-se ao professor Giacomoni, que assim definiu essa modulação orçamentária:

Um orçamento de desempenho é aquele que apresenta os propósitos e objetivos para os quais os créditos se fazem necessários, os custos dos programas propostos para atingir àqueles objetivos e dados quantitativos que meçam as realizações e o trabalho levado a efeito em cada programa. ${ }^{81}$

De tal conceituação, chega-se ao orçamento-programa, ora adotado no Brasil, no qual também se privilegia os fins em detrimento aos meios, tendo como elementos essenciais:

a) os objetivos e propósitos perseguidos pela instituição e para cuja consecução são utilizados os recursos orçamentários; b) os programas, isto é, os instrumentos de integração dos esforços governamentais no sentido de concretização dos objetivos; c) os custos dos programas medidos por meio da identificação dos meios ou insumos (pessoal, material, equipamentos, serviços etc.) necessários para a obtenção dos resultados; e d) medidas de desempenho com a finalidade de medir realizaçoes (produto final) e os esforços despendidos na execução dos programas. ${ }^{82}$

Apontados os elementos essenciais, percebe-se o afirmado por Machado Júnior, que vê no Orçamentoprograma um importante instrumento dirigido aos objetivos: "Somente, pois, quando se concebe o orçamento como meio de ligação efetivo entre o processo de planejamento e de finanças públicas é que essa técnica adquire toda a sua pujança em administração"s.

Segundo Martner, este tipo de orçamento mostra, em separado, os gastos com cada um dos projetos do Executivo e seus custos, permite, assim, alcançar a programação setorial dentro do governo com um alto grau de consistência e integração. Este tipo de orçamento trata de mostrar o custo das funções, dos programas e dos objetivos. ${ }^{84}$

Ressalta-se que há outros mecanismos orçamentários que, especialmente por ter se observado que são incompatíveis com planejamentos de médio e longo prazo, restaram infrutíferos, não obstante os fundamentos de se buscar meios de aprimoramento do tradicional e de especialização dos setores atinentes. É o caso do chamado Orçamento Base-Zero, cuja filosofia seria romper com passado. Ele surgiu nos EUA, na década de 1970 e de acordo com Paludo não havia direito adquirido no Orçamento, de forma que anualmente o gestor teria que provar a necessidade de cada gasto frente a outras prioridades e projetos. ${ }^{85}$

No Brasil, como determinado pela Constituição Federal, o orçamento deve conjugar projeções de médio e longo prazo no instrumento denominado PPA - Plano Plurianual e a concretude de curto prazo especificadas na LDO - Lei de Diretrizes Orçamentárias e na LOA - Lei Orçamentária Anual.

\footnotetext{
${ }^{81}$ GIACOMONI, op. cit., p. 166.

${ }^{82}$ GIACOMONI, op. cit., p. 166.

${ }^{83}$ MACHADO JÚNIOR, op. cit., p. 04.

${ }^{84}$ MARTNER, Gonzalo. A técnica do orçamento por programas e atividades. Rio de Janeiro: FGV, 1972.

${ }^{85}$ PALUDO, op. cit.
} 
Desta feita, o PPA tem uma função de planejamento, pelo que se depreende do artigo $165 \rrbracket 1^{\circ}$ da Constituição Federal:

A lei que instituir o plano plurianual estabelecerá, de forma regionalizada, as diretrizes, objetivos e metas da administração pública federal para as despesas de capital e outras delas decorrentes e para as relativas aos programas de duração continuada. ${ }^{86}$

Assim, já em consonância com a ideia de orçamento-programa, Machado Júnior conclui que " $O$ orçamento é um plano de trabalho, expresso em termos financeiros, para um determinado período de tempo, contendo os meios de financiamento das despesas governamentais e aprovado por uma lei" ${ }^{87}$

Tal definição, segundo o mesmo e já à luz de uma concepção de orçamento-programa, permite definir o orçamento como instrumento de planejamento; conceber um plano em termos financeiros; manter seu aspecto legal e limitar - no tempo e nas dotações - a autorização legislativa para a arrecadação da receita e aplicação dos dinheiros.

Há ainda uma prática orçamentária muito comum nas Administrações brasileiras, então não classificada pela maioria dos estudiosos do tema como uma técnica, dada justamente a sua forma rudimentar de negociação a meramente política - e a impossibilidade de correção de falhas existentes no processo, acarretando na repetição dos mesmos erros. Trata-se do Orçamento Incremental, assim definido: "[...] é aquele que, a partir dos gastos atuais, propóe um aumento percentual para o ano seguinte, considerando apenas o aumento ou diminuição dos gastos, sem análise de alternativas possíveis ${ }^{\text {"88 }}$

Nota-se nessa forma de orçar os gastos públicos um engessamento dos programas a serem desenvolvidos em benefício da comunidade.

Enfim, eis que começa a ser difundido no Brasil, ainda na década de 1980, o Orçamento Participativo, assim denominado nas cidades de Porto Alegre - RS e Santo André - SP, embora já se tivessem notícias de embriões desse modelo orçamentário desde a década de $1970 .{ }^{89}$

Para sua efetivação, entretanto, há a necessidade de intensa participação popular, sendo que uma das primeiras experiências de participação do povo numa grande cidade, no caso a maior do país, São Paulo, se deu na administração de Luiza Erundina entre 1989 e 1992, eleita pelo Partido dos Trabalhadores, legenda que desde suas origens tinha como opção "instaurar formas de participação popular que substituíssem a barganha parlamentar.90

Desde o início notaram-se contradições e ambiguidades, a exemplo dos conselhos instituídos de educação e saúde, revelando uma defasagem entre o discurso proposto e a prática.

\footnotetext{
${ }^{86}$ BRASIL. Constituição (1988). Constituição da República Federativa do Brasil. Brasília, DF: Senado, 1988.

${ }^{87}$ MACHADO JÚNIOR, op. cit., 02.

${ }^{88}$ PALUDO, op. cit., p. 13.

${ }^{89} \mathrm{Ibid}, \mathrm{p} .12$.

${ }^{90}$ COUTO, apud JACOBI, P. Políticas Sociais e Ampliação da Cidadania. Rio de Janeiro: FGV, 1990, p. 142.
} 
Como ensina Pedro Jacobi, reivindicações setoriais de curto prazo contaminavam as discussões, em contraposição àquelas metas estratégicas de médio e longo prazo. ${ }^{91}$

Logo se percebeu que havia familiaridade insuficiente da população na participação da elaboração das políticas públicas, a exceção de alguns poucos setores mais organizados, aptos a formular suas demandas. Para tanto, foi necessário modificar a estratégia governamental, no sentido de também voltar-se para aquela parcela não inserida nos movimentos populares, os quais, por sua vez, reclamaram a redução de seu peso político e a frustração de demandas há muito por eles pleiteadas.

Igualmente, tratando do desafio de superar a lógica tradicional para construir uma nova institucionalidade, Jacobi conclui:

A superação das barreiras sócio-institucionais cria condições propícias a uma efetiva democratização da gestão e à co-responsabilização na defesa do interesse geral. A cidadania exige, cada vez mais, novas formas de organização do Estado, notadamente o fortalecimento de uma esfera pública que seja capaz de agregar novos arranjos institucionais conducentes a práticas pluralistas e integradoras.

Trata-se de criar condiçōes para romper com a cultura política dominante e formular uma nova proposta de socialização baseada na educação para a participação. E esta se concretizará principalmente pela presença crescente de uma pluralidade de atores que sejam capazes de intervir conscientemente e sem tutela nos processos decisórios de interesse público, legitimando e consolidando propostas de gestão baseadas na garantia de acesso à informação. Donde se conclui que a criação de um espaço público não-estatal que se constitua numa arena democrática de negociação entre o Estado e a sociedade é condição indispensável para a governabilidade e a legitimidade. ${ }^{92}$

Nota-se uma forma de atuação popular direta que visa aproximar os cidadãos e suas demandas das ações do Estado, mas cuja eficácia depende de conscientização prévia acerca da importância da participação para o bem comum, por parte de todos os atores sociais envolvidos.

Por outro lado, as críticas ao modelo de participação popular devem ser destacadas, como aquelas elencadas por Félix Sánchez a partir de Joan Subiras, Diretor do Programa de Doutorado do Instituto de Governo e Políticas Públicas (IGOP) da Universidade Autônoma de Barcelona (UAB): “a participação aumenta a lentidão na tomada de decisóes" dada à quantidade de pessoas que tem que ser consultadas; "aumenta os custos na tomada de decisóes"; "não incorpora valor agregado à decisão", eis que a maioria dos opinantes são leigos; "provoca um excesso de particularismos"e "somente leva em conta o curto prazo"- questões estas explicitadas na experiência paulistana - e a "participação direta provoca a erosão de instituições e partidos", então legítimos representantes do povo. ${ }^{93}$

A pouca participação também é elencada, baseada na mesma obra: "os cidadãos de fato não querem participar" eis que "[...] não querem se envolver realmente no processo complicado e cansativo que caracteriza

\footnotetext{
${ }^{91}$ JACOBI, op. cit.

92 Ibid., p. 145-146.

${ }^{93}$ SÁNCHEZ, Felix. Orçamento Participativo: teoria e prática. 2002. São Paulo: Cortez, 2002, p.53. 
qualquer tomada de decisóes públicas."; "os cidadãos, quando participam, o fazem de uma forma muito inconstante" dificultando o funcionamento regular das instâncias participativas; "os cidadãos dispostos a participar são sempre os mesmos"; "os cidadãos que se mobilizam e pretendem participar, muitas vezes, só representam a si próprios e aos seus interesses."94

Sánchez, por sua vez, não concorda com tais críticas por ele compiladas, a ponto de afirmar que:

Se os argumentos contra a participação democrática são esses que resumimos, fica cada vez mais difícil aceitar e justificar que os simples cidadãos não sejam considerados capazes de tomar decisões políticas corriqueiras. A universalização do acesso à educação fundamental e os progressos na disseminação do conhecimento e da informação limitam fortemente os argumentos contrários à participação cidadã. ${ }^{95}$

O mesmo autor chama a atenção para a necessidade de aprimoramento dos meios de tecnologia da informação e de valorização dos conselhos gestores, no intuito de desenvolver a participação popular.

Concordando com Sánchez, constatamos que a par dos inevitáveis desvios e imperfeições do modelo de participação popular direta na elaboração das políticas, programas e dos orçamentos públicos, engendrados, entre outros fatores, pela ausência de prática democrática contínua, este ainda é o modelo que mais se aproxima do ideal democrático e o que reúne melhores condições de proporcionar a concretização dos direitos fundamentais sociais, a partir dos instrumentos de gestão dos recursos públicos.

Com efeito, ao revés do postulado afastamento da população do processo de elaboração orçamentária, entendemos que esforços devem ser realizados para suprir o déficit informacional, técnico e jurídico que ostentam, permitindo uma participação qualificada no processo, que resultaria em evidentes ganhos para o Estado Democrático de Direito.

Decerto que a Constituição Federal de 1988 não trata expressamente da participação popular nos orçamentos. O que há mais próximo de participação do povo na tomada de decisões é um preceito de cooperação das associações representativas no planejamento municipal, previsto no artigo 29, inciso XII, embrião da gestão orçamentária participativa disposta na Lei Federal 10.257, de 10 de julho de 2001, o Estatuto da Cidade, disciplinador da execução da política urbana, de que tratam os artigos 182 e 183 do mesma carta constitucional.

$\mathrm{Na}$ área da saúde a Lei Federal 8.142/1990, que dispõe sobre a participação da comunidade na gestão do Sistema Único de Saúde (SUS) e os repasses financeiros da área, estabelece a existência de conselhos e a realização de conferências de saúde como um dos pré-requisitos para tais repasses.

\footnotetext{
${ }^{94}$ Ibid., p. 54.

${ }^{95}$ Ibid. p. 55.
} 
Merece relevo ainda, a recente previsão normativa, consubstanciada no Decreto no 8.243, de 23 de maio de $2014^{96}$, que instituiu a Política Nacional de Participação Social - PNPS e o Sistema Nacional de Participação Social - SNPS que enuncia a participação social como método de governo.

Adverte-se, entretanto, que o orçamento participativo, na forma conhecida, só foi instituído na capital paulista em 2001, com o retorno do Partido dos Trabalhadores ao poder, na gestão de Marta Suplicy. ${ }^{97}$

Assim, a pioneira da efetivação do orçamento participativo numa grande capital é Porto Alegre, cujos princípios norteadores foram:

a) Regras universais de participação em instâncias institucionais e regulares de financiamento; b) um método objetivo de definição dos recursos para investimentos, que perfazem um ciclo anual de atividades públicas de orçamentação do Município; e c) um processo decisório descentralizado tendo por base a divisão da cidade em 16 regiões orçamentárias. ${ }^{98}$

Além disso, referido instrumento submete-se a três instâncias aptas a realizar a mediação entre a população e o Poder Executivo, também enumeradas no caso porto-alegrense.

b) Unidades administrativas e órgãos técnicos internos ao Executivo Municipal voltados especialmente para o gerenciamento e o processamento técnico-político da discussão orçamentária com os moradores(...); b) instâncias comunitárias, autônomas em relação à Administração Municipal, formadas, principalmente por organizações de base regional na cidade, que articulam a participação dos moradores e a escolha das prioridades das regiōes da cidade. (...); c) instâncias institucionais permanentes de participação comunitária - como o Conselho do Plano de Governo e Orçamento (chamado de Conselho do Orçamento Participativo $=$ COP), Assembleias Regionais, Fórum Temático do Orçamento - encarregados dos procedimentos concernentes à sua dinâmica de modo a viabilizar a co-gestão dos recursos públicos e a prestação de contas do Executivo às comunidades sobre decisões na alocação das verbas orçamentárias. ${ }^{99}$

Quanto ao processo de participação, seu o ciclo anual se dá em três etapas:

c) (...) realização das Assembleias Regionais e Temáticas; 2) Formação das instâncias institucionais de participação, tais como o Conselho do Orçamento e os Fóruns de Delegados; 3) discussão do orçamento do Município e aprovação do Plano de

\footnotetext{
${ }^{96}$ BRASIL, 2014. Decreto no8.243, de 23 de maio de 2014:

(...) art. $3^{\circ}$ São diretrizes gerais da PNPS:

I - reconhecimento da participação social como direito do cidadão e expressão de sua autonomia;

II - complementariedade, transversalidade e integração entre mecanismos e instâncias da democracia representativa, participativa e direta;

III - solidariedade, cooperação e respeito à diversidade de etnia, raça, cultura, geração, origem, sexo, orientação sexual, religião e condição social, econômica ou de deficiência, para a construção de valores de cidadania e de inclusão social;

IV - direito à informação, à transparência e ao controle social nas ações públicas, com uso de linguagem simples e objetiva, consideradas as características e o idioma da população a que se dirige;

V - valorização da educação para a cidadania ativa;

VI - autonomia, livre funcionamento e independência das organizações da sociedade civil; e

VII - ampliação dos mecanismos de controle social.

${ }^{97}$ SÁNCHEZ, op. cit.

${ }^{98}$ FEDOZZI, Luciano. Orçamento Participativo: Reflexões sobre a experiência de Porto Alegre. 1997. Rio de Janeiro: Tomo Editorial, p.111.

${ }^{99}$ FEDOZZI, op. cit., p. 113-115. Sobre as instâncias comunitárias FEDOZZI esclarece que existem diversos graus de organização, que na capital gaúcha são chamadas de Conselhos Populares, União de Vilas ou Articulações Regionais.
} 
Investimentos pelos representantes dos moradores no Conselho do Orçamento Participativo. ${ }^{100}$

Após, há a necessidade de distribuir os finitos recursos para as regiões e temas eleitos, conforme hierarquização atribuída pela população participante e os critérios objetivos definidos pelo Conselho do Orçamento, em cada qual são atribuídas notas.

d) (...) Estes critérios são: 1) a carência do serviço ou infraestrutura urbana, conforme dados fornecidos pela Prefeitura e avaliação conjunta entre essa e os representantes comunitários; 2) População em áreas de carências máxima, conforme uma estimativa do número de habitantes nas vilas que não possuem níveis mínimos de infra-estrutura e serviços urbanos; 3 ) População total da região do Orçamento Participativo; 4) Prioridade atribuída pela região, aos setores de investimentos demandados por ela. ${ }^{101}$

Luciano Fedozzi enxerga no Orçamento Participativo, fundando-se em Max Weber ${ }^{102}$, que a participação popular é capaz sim de racionalizar a política e impedir um modelo patrimonialista e voltado a particularismos, o que reforça o posicionamento de Félix Sánchez supracitado.

Ora, o método do Orçamento Participativo, ao primar por regras universais de participação e por critérios objetivos e impessoais para a seleção das prioridades reivindicadas pelas comunidades, estabelece uma dinâmica de acesso aos recursos públicos, que se opõe ao particularismo da justiça de gabinete (Weber, 1992) como prática tradicional que caracteriza a gestão patrimonialista. ${ }^{103}$

Percebe-se que tal metodologia orçamentária cria condições, inclusive, para uma maior fiscalização social dos gestores públicos - dada à essencialidade da prestação de contas (Acoutabilly) - além de evitar clientelismos, particularismos, na medida em que os critérios de gastos públicos são objetivamente predeterminados.

Adverte-se que nem sempre as comunidades participantes, em seus seios, optam por seguir exatamente as diretrizes objetivas propostas pelo Conselho do Orçamento, a exemplo do que ocorrera em Porto Alegre "optando-se pela negociação política e o voto direto dos delegados de cada vila para a escolha das prioridades da região"como explicou Luciano Fedozzi. ${ }^{104}$

O mesmo autor ainda pondera essa preferência pela participação quantitativa dos moradores, em detrimento a forma tecnicamente sugerida:

A valorização da participação quantitativa interna às regiões, por sua vez, pode aludir à existência de práticas comunitárias tradicionais - como lideranças carismáticas e/ou paternalistas - que, ao promoverem "inchaços" na participação, podem estar reproduzindo um tipo de "clientelismo comunitário". Entretanto, conforme alertado na hipótese geral que presidiu o presente estudo, faz uma enorme diferença sociológica verificar se o modelo institucional é favorecedor ou não das condições estruturais para a instituição da cidadania. $^{105}$

\footnotetext{
${ }^{100}$ Ibid., p. 115.

${ }^{101}$ Ibid., p. 126.

${ }^{102}$ Apud FEDOZZI, op. cit., p. 126.

${ }^{103}$ FEDOZZI, op. cit., p. 154.

${ }^{104} \mathrm{Ibid}$, p. 161.

${ }^{105}$ Ibid., p. 161
} 
Não há que se afastar também a resistência dos membros do Poder Legislativo, que em função da participação dos cidadãos mediante esse canal direto com o Executivo, a qual sugere uma percepção de que o poder daqueles é diminuído não só em função de restar ameaçada a barganha política, presente na atividade parlamentar, bem como por eventuais aversões ao Poder Legislativo por parte de grupos mais organizados, mais uma vez a exemplo do que ocorreu em Porto Alegre - RS.

Ao final da primeira gestão da Administração Popular (1992), o deslocamento de poder a favor da participação popular na gestão municipal parece ter gestado - contraditoriamente ao caráter democrático expresso pela nova Lei Orgânica Municipal de 1990 -, por um lado, sérias resistências do Legislativo às novas formas de participação direta da população e, por outro, uma posição de aversão política dos movimentos comunitários mais organizados aos Vereadores, quase uma negação da importância política as instituições legislativas para a democracia. Concepção essa plenamente expressa, por exemplo, na posição dos membros do Conselho do Orçamento no momento em que são discutidos os percentuais de recursos orçamentários que devem ser destinados anualmente à Câmara de Vereadores. ${ }^{106}$

Deste episódio de questionamentos por parte de conselhos populares, quanto às verbas orçamentárias para a manutenção do Poder Legislativo, extrai-se que o descontentamento com os mandatários de cargos políticos ao mesmo tempo em que pode estimular a participação direta, é capaz de abalar as instituições constitucionalmente estabelecidas para também democraticamente discutir as demandas da coletividade.

Destarte, frente ao paradoxo entre a limitação orçamentária e as crescentes demandas da população, a modalidade participativa proporciona um orçamento mais realista, exposto por Fedozzi como um "orçamentoverdade", em oposição às peças meramente ficcionais confeccionadas no sentido de atender práticas patrimonialistas.

Além disso, tomando como referência o supracitado estudo do mesmo autor, nota-se uma tendência a efetividade dos programas em prol da coletividade, fulcrada em estatísticas apresentadas sob tal modelo referencial porto-alegrense, onde, por exemplo, entre os participantes das Assembleias Regionais e Temáticas do ano de 1995, 56,54\% das pessoas já tinham sido beneficiadas por obras e serviços previstos em tal modalidade orçamentária, percentual que aumenta para 67,86\% quando os atingidos são aqueles dirigentes de Associações de Moradores e ainda maior entre os mandatários das respectivas instâncias de representação (delegados e conselheiros), $74,25 \%{ }^{107}$

Isso demonstra a consonância desse instrumento com o que se denomina de direito ao desenvolvimento, que de acordo com Flávia Piovesan contempla três dimensões centrais, a saber: justiça social; participação e accountability, bem como programas e políticas nacionais e cooperação internacional.

É dever dos Estados encorajar a participação popular em todas as esferas como um importante fator ao direito ao desenvolvimento e à plena realização dos direitos humanos.

\footnotetext{
${ }^{106}$ Ibid. p. 165.

${ }^{107}$ FEDOZZI, op. cit.
} 
Estados devem promover e assegurar a livre, significativa e ativa participação de indivíduos e grupos na elaboração, implementação e monitoramento de políticas de desenvolvimento. ${ }^{108}$

Diante de tal quadro, retoma-se o questionamento inicial: como garantir a concretização dos direitos fundamentais sociais através de políticas e orçamentos públicos?

A resposta a tal indagação perpassa, obrigatoriamente, pelo fortalecimento da gestão democrática e dos mecanismos de participação popular na formulação, gestão, controle, avaliação e correção das políticas, dos programas e dos orçamentos públicos, tendo por norte a efetivação dos objetivos fundamentais do Estado brasileiro, padrão hermenêutico e teleológico de toda produção normativa nesta seara.

Diante de tal quadro, retoma-se o questionamento inicial: como garantir a concretização dos direitos fundamentais sociais através de políticas e orçamentos públicos?

A resposta a tal indagação perpassa, obrigatoriamente, pelo fortalecimento da gestão democrática e dos mecanismos de participação popular na formulação, gestão, controle, avaliação e correção das políticas, dos programas e dos orçamentos públicos, tendo por norte a efetivação dos objetivos fundamentais do Estado brasileiro, padrão hermenêutico e teleológico de toda produção normativa nesta seara.

Sustenta-se, assim, a existência de um dever fundamental de planejamento e de um correspectivo direito público subjetivo de participação democrática na elaboração, implementação, gestão, controle e ajustes das políticas públicas tendentes à concretização dos direitos fundamentais sociais.

Eis, dessa forma, a importância de pesquisas para o desenvolvimento de instrumentos, que como o exposto, alavancam a participação popular qualificada e, por consequência, a efetivação dos direitos fundamentais sociais

\section{CONCLUSÃO}

O presente artigo, fase inicial da pesquisa que objetiva investigar o papel do orçamento como instrumento de controle de políticas públicas, nesta etapa de fundamentação teórica, tratou do papel dos instrumentos de planejamento na efetivação dos direitos fundamentais e sociais.

Para tanto, foi necessário introduzir conceitos e diferenciações também de outros institutos que eventualmente são enleados ou correlacionados, em especial: os princípios e o Estado Democrático de Direito.

Mostrou-se evidente o papel do Estado na efetivação de políticas que objetivem concretizar tais direitos, levando-se em conta as diferenças entre os atores sociais envolvidos, as quais variações de interesses são inerentes à heterogeneidade, pelo que meios de provocar a convergência vem sendo constantemente aprimorados.

${ }^{108}$ PIOVESAN, Flávia. Temas de Direitos Humanos. 4. ed. São Paulo: Saraiva, 2010, p.139. 
Além disso, trazendo a discussão ao cenário brasileiro, muito embora a Carta Cidadã de 1988 contemple um amplo catálogo de direitos fundamentais, numa sociedade pretensamente justa, fraterna e pluralista, dentre outros preceitos estampados desde o preâmbulo da mesma, resta muito para concretizar tais direitos, quando o Estado se coloca como sujeito passivo das posições jurídicas e das relações obrigacionais respectivas.

Nesse sentido, a justificativa de limitação orçamentária, há muito propagada pelos entes estatais, não merece perpetuar-se frente a evolução de mecanismos de planejamento, aos quais aqueles tem o dever constitucional de aplicá-los.

Uma das principais expressões do dever estatal de planejamento está nos instrumentos orçamentários, expressos no artigo 167 da Constituição pátria: Plano Plurianual; Lei de Diretrizes Orçamentárias e Orçamentos Anuais. Porém, há que observar, a luz do ensinamento de Américo Bedê Freire Júnior, referenciado, que mesmo essa sistemática carece de distorções, tanto no aspecto de mérito administrativo, quanto no de efetivação das políticas previstas, o que mostra imprescindível o monitoramento constante, sem embargo da possibilidade de intervenção do Poder Judiciário, em contraposição ao aclamado Princípio da Reserva do Possível.

Frente a tudo isso, a participação popular na elaboração dos orçamentos e no acompanhamento de sua execução vem sendo defendida como respeitável meio de se vislumbrar um planejamento ainda mais próximo das demandas dos cidadãos.

Não obstantes programas oficiados pelos próprios governos, a exemplo do plano federal "Brasil Sem Miséria”, a participação popular já se mostra eficaz em conselhos obrigatórios, a serem instituídos nos entes federativos, e pela prática do chamado "Orçamento Participativo". Sobre esta sistemática ainda não impositiva, analisando-se as experiências piloto de São Paulo - SP e mais concretamente de Porto Alegre - RS e, num primeiro momento, abstraindo-se suas dificuldades, distorções e resistências de parte dos atores envolvidos, a satisfação das demandas coletivas acentuou-se frente ao modelo orçamentário tradicional.

Isto posto, conclui-se que a profissionalização da Administração Pública brasileira, assim como o fortalecimento da gestão democrática e dos mecanismos de participação popular na formulação, gestão, controle, avaliação e correção das políticas, dos programas e dos orçamentos públicos, tendo por parâmetro a efetivação dos objetivos fundamentais do Estado brasileiro, constituem requisitos indispensáveis para reversão do quadro de distanciamento entre a abstrata previsão normativa e a concretização efetiva dos direitos fundamentais sociais, em prestígio ao Estado Democrático de Direito. 


\title{
THE ACHIVIEMENT OF FUNDAMENTAL SOCIAL RIGHTS THROUGH POLICY AND PUBLIC BUDGETS
}

\begin{abstract}
:
This study aims to investigate the role of planning instruments in effective social fundamental rights, in particular of public policies and budgets. The research used the hypothetical-deductive method, from the readback of the doctrine on this subject production, with practical experience represented by models that set out to overcome the huge gap between abstract normative prediction and the achievement of fundamental social rights in the real world. From the delimitation of the concept of public policy, sought to clarify the relationship between public policy and democratic rule of law, outlining the contours of its anatomy and functionality. It also sought to understand the relationship between public policy and fundamental rights, in particular the role that those engaged in the fulfillment of such genre. To reach this goal, developed the idea of prohibition of inadequacy and the inertia in the production and implementation of public policies aimed at the achievement of fundamental rights. Similarly, investigated the role of the budget in control of the effectiveness of the implementation of the social fundamental rights and their relationship with the principle of democratic management.
\end{abstract}

Keywords: Budget; Public policies; Fundamental rights.

\section{REFERENCIAS}

ALEXY, Robert. Teoria dos direitos fundamentais. 2. ed. São Paulo: Malheiros, 2012.

ARISTÓTELES. Política. Disponível em: <http://www.dominiopublico.gov.br>. Acesso em: 07 jul. 2013.

Política. Trad. Torrieri Gumarães. São Paulo: Martin Claret, 2001.

BALEEIRO, Aliomar. Uma Introdução à Ciência das Finanças. 9. ed. Rio de Janeiro: Forense: 1973.

BERNARD, Wesley de Oliveira Louzada. O princípio da dignidade da pessoa humana e o novo direito civil: breves reflexões. Revista da Faculdade de Direito de Campos, ano VII, n. 8, jun. 2006.

BOBBIO, Norberto; MATTEUCCI, Nicola; GIANFRANCO, Pasquino. Dicionário de Política. Brasília: UnB, 1998.

BRASIL. Ministério do Desenvolvimento Social. Disponível em: <www.mds.gov.br>. Acesso em: 07 jul. 2013.

BURKHEAD, Jesse. Orçamento Público. Rio de Janeiro: Fundação Getúlio Vargas, 1971.

CANELA JUNIOR, Osvaldo. Controle judicial de políticas públicas. São Paulo: Saraiva, 2011.

COUTO, C. O desafio de ser governo: O PT na prefeitura de São Paulo. Paz e Terra, São Paulo, 1995. Apud Jacobi, P. Políticas Sociais e Ampliação da Cidadania. FGV, Rio de Janeiro, 1990.

DALLARI, Adilson Abreu; FERRAZ, Sérgio (Org.) Estatuto da Cidade: comentários à Lei Federal 10.257/2001. 2. ed. São Paulo: Malheiros, 2006. 
DIAS, Reinaldo; MATOS, Fernanda. Políticas Públicas: princípios, propósitos e processos. São Paulo: Atlas, 2012.

DWORKIN, Ronald. Levando os direitos a sério. Trad. Nelson Boeira. São Paulo: Martins Fontes, 2011.

FARAH JUNIOR, Moisés F. Orçamento público e gestão governamental. In: SILVA, Christian Luiz da (Org.) Políticas Públicas e Desenvolvimento Local. Instrumentos e proposições de análise para o Brasil. Petrópolis: Vozes, 2012.

FEDOZZI, Luciano. Orçamento Participativo: Reflexões sobre a experiência de Porto Alegre. Rio de Janeiro: Tomo Editorial, 1997.

FERRAJOLI, L. Diritti Fondamentali - Un dibattito teórico. A cura di E. Vitale. Roma: Libri del Tempo, 2008.

FREIRE JUNIOR, Américo Bedê. O controle judicial de políticas públicas. São Paulo: Revista dos Tribunais, 2005.

GIACOMONI, James. Orçamento Público. São Paulo: Atlas, 2010.

GRAU, Eros Roberto. O direito posto e o direito pressuposto. São Paulo: Malheiros, 2003, p.

GRINOVER, Ada Pelegrini. O Controle de Políticas Públicas pelo Poder Judiciário. Revista do Curso de Direito da Faculdade de Humanidades e Direito, v. 7, n. 7, p. 25, 2010.

JACOBI, P. Políticas Sociais e Ampliação da Cidadania. Rio de Janeiro: FGV, 1990.

MACHADO JUNIOR, José Teixeira. Racionalização da Elaboração Orçamentária através do OrçamentoPrograma IBAM: Mímeo, 2011.

MARTNER, Gonzalo. A técnica do orçamento por programas e atividades. Rio de Janeiro: FGV, 1972.

MENDES, Gilmar Ferreira; COELHO, Inocêncio Mártires; BRANCO, Paulo Gustavo Gonet. Curso de Direito Constitucional. São Paulo: Saraiva, 2009.

PALUDO, Augustinho. Orçamento Público, Administração Financeira e Orçamentária e Lei de Responsabilidade Fiscal. 3. ed. Rio de Janeiro: Elsevier, 2012.

PELUSO, Cesar. "Direitos fundamentais: conceito, eficácia e perspectivas". Palestra proferida em 20/05/2013, durante o Curso de Aperfeiçoamento São Paulo: Fundação Armando Álvares Penteado, 2013.

PIOVESAN, Flávia. Temas de Direitos Humanos. 4. ed. São Paulo: Saraiva, 2010, p.139.

RAMPAZZO, L. Metodologia Científica: para alunos dos cursos de graduação e pós-graduação. 6. ed. São Paulo: Loyola, 2011.

RODRIGUES, Marta M. A. Políticas públicas. São Paulo: Publifolha, 2011. 
RUA, Maria das Graças. Políticas Públicas. CAPES: UAB, 2009.

SÁNCHEZ, Felix. Orçamento Participativo: teoria e prática. 2002. São Paulo: Cortez, 2002.

SARLET, Ingo Wolfgang. A eficácia dos direitos fundamentais. 9. ed. Porto Alegre: Livraria do Advogado, 2007.

SECCHI, Leonardo. Políticas públicas: conceitos, esquemas de análise, casos práticos. São Paulo: Cengage Learning, 2010.

SILVA, José Afonso. Curso de direito constitucional positivo. 22. ed. São Paulo: Malheiros, 2003.

Trabalho enviado em 18 de maio de 2014.

Aceito em 12 de agosto de 2014. 